\title{
INFILTRAÇÃO APICAL EM OBTURAÇÕES DE CANAIS REALIZADAS COM DOIS TIPOS DE CIMENTO APÓS APLICAÇÃO DO LASER ND:YAG OU SOLUÇÃO DE EDTA NAS PAREDES DO CANAL RADICULAR
}

\section{LEANDRO DE OLIVEIRA BASSILI}

Dissertação apresentada à Faculdade de Odontologia de Bauru, da Universidade de São Paulo, como parte dos requisitos para obtenção do grau de Mestre em Odontologia - Área de Endodontia.

(Edição Revisada)

BAURU

2002 


\section{INFILTRAÇÃO APICAL EM OBTURAÇÕES DE CANAIS REALIZADAS COM DOIS TIPOS DE CIMENTO APÓS APLICAÇÃO DO LASER ND:YAG OU SOLUÇÃO DE EDTA NAS PAREDES DO CANAL RADICULAR}

\section{LEANDRO DE OLIVEIRA BASSILI}

Dissertação apresentada à Faculdade de Odontologia de Bauru, da Universidade de São Paulo, como parte dos requisitos para obtenção do grau de Mestre em Odontologia - Área de Endodontia.

(Edição Revisada)

Orientador: Prof. Dr. Ivaldo Gomes de Moraes

BAURU

2002 


Bassili, Leandro de Oliveira
B294i Infiltração apical em obturações de canais relaizadas
com dois tipos de cimento após aplicação do laser Nd:YAG ou
solução de EDTA nas paredes do canal radicular./Leandro de
Oliveira Bassili. - Bauru, 2002.
$75 p .:$ il.; $31 \mathrm{~cm}$.
Dissertação. (Mestrado) -- Faculdade de Odontologia de
Bauru. Universidade de São Paulo.
Orientador: Prof. Dr. Ivaldo Gomes de Moraes

Autorizo, exclusivamente para fins acadêmicos e
científicos, a reprodução total ou parcial desta
dissertação/tese, por processos fotocopiadores e outros
meios eletrônicos.
Assinatura:

\section{Comitê de Ética da FOB}

Processo $N^{\circ}:$ 088/2002

Data da aprovação: 24/09/2002 


\section{DADOS CURRICULARES}

\section{Leandro de Oliveira Bassili}

Nascimento

Filiação

$1992-1996$

$1997-1998$

$1999-2001$

$2001-2002$

2002
04 de Maio de 1974

Rio de Janeiro - RJ

Wilson Elias Bassili

Ilda de Oliveira Bassili

Curso de Odontologia - Universidade Federal Fluminense - UFF-RJ

Curso de Especialização em Endodontia na Faculdade de Odontologia de Bauru - USP

Professor do Curso de Atualização em Endodontia $A B O$ - Niterói

Curso de Pós-Graduação em Endodontia, nível mestrado, na Faculdade de Odontologia de Bauru - USP

Professor do Curso de Especialização em Endodontia ABO - Niterói 
Dedico este trabalho

Aos meus pais Wilson e Ilda que sempre me apoiaram em todas as decisões que tomei, estando ao meu lado, com muito amor e carinho, comemorando nossas conquistas e me apoiando em todos os momentos difíceis.

À Elaine pela paciência e ajuda para a realização deste trabalho, e pela compreensão deste momento difícil e importante pelo qual passamos.

Ao meu irmão Sandro, a minha cunhada Fernanda, e também às minhas sobrinhas Carolina e Rafaela.

Amo muito vocês. 


\section{Agradeço especialmente}

Ao Prof. Dr. Ivaldo Gomes de Moraes, que esteve presente em todas as etapas deste trabalho, cumprindo com destreza e sabedoria a sua função de orientador $e$, ao mesmo tempo, sendo uma pessoa com todas as virtudes de um amigo.

Muito obrigado Professor Ivaldo. 


\section{Agradeço ainda}

Aos Profs. Drs. Alceu Berbert, Clovis Monteiro Bramante, Norberti Bernardinelli e Roberto Brandão Garcia, por tudo que me ensinaram, colaborando de forma expressiva para minha formação profissional, além da amizade e respeito que tem por mim.

Ao Prof. Dr. José Roberto Pereira Lauris pela realização da análise estatística deste trabalho.

À Dr. ${ }^{a}$ Raquel Virginia Zanetti por ceder o equipamento laser Nd:YAG e 0 espaço em seu consultório para realização da pesquisa . 
Aos professores e amigos, Henrique Oliveira, Hélio Lopes, Shirley de Souza, Ary Gomes da Motta, Isabel Coelho, Nelson Graça, Evan de Souza e Ney Salgado, pelo incentivo e pela confiança que sempre tiveram pelo meu trabalho.

\section{Meu muito obrigado.}

À equipe da Disciplina de Endodontia, da Faculdade de Odontologia, da Universidade Federal Fluminense, a qual ensinou-me os primeiros passos na Endodontia e, com a qual, pude trabalhar, formando alunos para a prática desta especialidade.

Obrigado. 
Aos colegas de Mestrado, Giovana, Everdan, Renato, Sérgio, Fernanda, Jazzmina e Maristela, pela amizade e ajuda que tive de vocês durante o curso.

À amiga Fernanda Gomes de Moraes, por todo carinho e atenção, e pela troca de conhecimentos na realização deste trabalho. $O$ meu muito obrigado.

Aos amigos Ulisses Xavier e Vitor Brochado, pela constante troca de conhecimentos, e acima de tudo pela amizade e companheirismo para com minha pessoa.

À amiga Silvana Beltrami por toda atenção e carinho que teve por mim.

À todos os colegas da Pós - Graduação, pela ajuda e amizade nessa importante passagem de nossas vidas.

À bibliotecária Rita C. Paglione, por toda ajuda, sempre com muita simpatia, e pela revisão deste trabalho.

Aos funcionários da Endodontia, Edimauro, Neide e Suely, pelo carinho e atenção com que me tratavam, me ajudando sempre que preciso.

À equipe de funcionários, do setor de cópias da biblioteca da USP - Bauru, que sempre estavam dispostos a ajudar quando solicitados. Muito obrigado.

À todos que colaboraram para realização deste trabalho. 


\section{SUMÁRIO}

LISTA DE TABELAS

viii

LISTA DE FIGURAS

ix

LISTA DE ABREVIATURA E SÍMBOLOS

xi

RESUMO

xii

1 INTRODUÇÃO

1

2 REVISÃO DE LITERATURA

6

3 PROPOSIÇÃO

34

4 MATERIAL E MÉTODOS 36

5 RESULTADOS

51

6 DISCUSSÃO 56

7 CONCLUSÕES 64

REFERÊNCIAS BIBLIOGRÁFICAS 66

ABSTRACT

APÊNDICE 


\section{LISTA DE TABELAS}

pág

Tabela 1 Médias de infiltração marginal apical, em milímetros e, desvios padrão, obtidos em função dos tratamentos da parede do canal radicular $e$ dos cimentos utilizados na obturação

Tabela 2 Análise de variância a dois critérios

53 


\section{LISTA DE FIGURAS}

Figura 1

Figura 2

Figura 3

Figura 4

Figura 5

Figura 6

Figura 7

Figura 8

Figura 9

Figura 10

Figura 11
Aparelho de laser Nd:YAG (SMARTY-10)

42

Solução de EDTA trissódico

42

43

Cimento obturador AH Plus

43

Cimento obturador Endofill

44

Fibra óptica de 200 micrometros
diâmetro para aplicação do raio laser

Infiltração apical da solução de azul de metileno - irrigação final com EDTA e obturação com o cimento Endofill

45

Infiltração apical da solução de azul de metileno - irrigação final com EDTA e obturação com o cimento AH Plus

Infiltração apical da solução de azul de metileno - irradiação com laser $e$ obturação com o cimento Endofill

Infiltração apical da solução de azul de metileno - irradiação com laser $e$ obturação com o cimento AH Plus

Fotomicrografia da parede do terço médio do canal radicular após aplicação do EDTA (aumento de 1000x)

Fotomicrografia da parede do terço apical do canal radicular após aplicação do EDTA (aumento de 1000x) 
Figura 12

Figura 13

Figura 14
Fotomicrografias da parede do terço apical do canal radicular irradiada pelo laser (aumento de 1000x)

48

Fotomicrografias da parede do terço médio do canal radicular irradiada pelo laser (aumento de 1000x)

49

Representação gráfica das médias de infiltração apical, em milímetros, propiciada pelos diferentes grupos 


\section{LISTA DE ABREVIATURA E SÍMBOLOS}

$\begin{array}{ll}\text { EDTA } & \text { Ácido etilenodiaminotetraacético } \\ \text { Nd:YAG } & \text { Íons neodímio e cristais de ítrio, alumínio e granada } \\ \text { W } & \text { Watt } \\ \text { mJ } & \text { MiliJoule } \\ \text { Hz } & \text { Pulsos por segundo } \\ \text { Pps } & \text { Microscopia eletrônica de varredura } \\ \text { M.E.V. } & \end{array}$




\section{RESUMO}

Avaliou-se a influência da aplicação do laser Nd:YAG ou solução de EDTA nas paredes de canais radiculares, sobre a capacidade seladora de obturações realizadas com dois tipos de cimento. Utilizou-se sessenta e oito dentes pré-molares inferiores humanos, dos quais sessenta e dois foram usados para analisar o selamento apical e seis para analisar as características das paredes dos canais radiculares sob M.E.V, após o tratamento pelo EDTA trissódico e pelo laser Nd:YAG. Os dentes tiveram suas coroas cortadas na junção cemento - esmalte e os canais radiculares foram instrumentados pela técnica automatizada com padronização dos forames apicais por uma lima tipo Kerr $n^{\circ}$ 25. Terminada a instrumentação dos canais, as superfícies externas radiculares foram impermeabilizadas, exceto o forame apical. As raízes foram, então, divididas em 4 grupos de 15, de acordo com o tipo de tratamento realizado nas paredes dos canais radiculares e o tipo de cimento utilizado para a mesma. Grupo I - aplicação do laser Nd:YAG e obturação com cimento AH Plus; Grupo II - aplicação do laser Nd:YAG e obturação com cimento Endofill; Grupo III aplicação de EDTA por 5 minutos e obturação com cimento AH Plus; Grupo IV aplicação de EDTA por 5 minutos e obturação com cimento Endofill. Dois dentes serviram de controles negativo e positivo. Em seguida, as raízes foram imersas em solução de azul de metileno a $2 \%$, durante 48 horas. Após a remoção da impermeabilização foi realizado o desgaste das raízes para leitura da magnitude das infiltrações, por meio de um microscópio óptico pela técnica da planimetria. Os resultados indicaram que o cimento AH Plus foi o que permitiu menor infiltração apical, assim como a aplicação do laser Nd:YAG, quando utilizado no tratamento das paredes dos canais radiculares, anteriormente à obturação. 
1 INTRODUÇÃO 


\section{INTRODUÇÃO}

O tratamento endodôntico tem como principais objetivos, propiciar uma eficiente limpeza do canal radicular a fim de eliminar restos teciduais, microorganismos e ao mesmo tempo dilatá-lo para que seja possível realizar uma obturação tridimensional impermeável, isolando o sistema de canais do resto do organismo.

A efetividade de vários métodos de limpeza dos canais vem sendo estudada, mas a maioria dos pesquisadores concorda que não há um instrumento ou técnica capaz de produzir o alargamento do canal sem que se produza raspas de dentina e se forme a "smear layer".

A "smear layer" tem uma aparência amorfa, irregular e granular quando observada ao M.E.V., imagem esta, formada pelo esfregaço dos componentes superficiais da parede do canal radicular, durante a fase de instrumentação. Sua espessura varia de 1 a 5 micrometros, sendo constituída por material orgânico e inorgânico, entre eles, raspas de dentina, tecido pulpar e bactérias.

As vantagens ou desvantagens da presença da "smear layer" na parede dos canais e a necessidade ou não de sua remoção anteriormente à obturação do sistema de canais radiculares, vêm sendo pesquisadas e os resultados são controversos. MOSS: ALLEMANG; JOHNSON50, em 2001, realizaram uma pesquisa com alunos de graduação, especialização em endodontia $e$ endodontistas, membros da AAE, para saber a conduta clínica em relação à remoção da "smear layer", anteriormente à obturação do sistema de canais radiculares. Os autores concluíram que $48,9 \%$ dos endodontistas afirmaram não remover a "smear layer" anteriormente à obturação. Em relação aos alunos de 
graduação e especialização, $78,6 \%$ e $64,5 \%$ respectivamente, afirmaram não remover a "smear layer". Entre os entrevistados que afirmaram remover a "smear layer", a maioria utilizava a solução de EDTA para esse fim.

A capacidade da "smear layer" agir como uma barreira física para as bactérias e seus subprodutos, impedindo-os de penetrar na dentina, foi demonstrada por alguns autores ${ }^{16,47}$. Em contra partida, YAMADA et al. ${ }^{73}$, em 1983, e BAKER et al.$^{5}$, em 1975, observaram que as bactérias podem se manter na "smear layer" e nos túbulos dentinários após a instrumentação dos canais radiculares e, então, sobreviverem e se multiplicarem.

GETTLMAN; MESSER; ELDEEB ${ }^{24}$ (1991); OKSAN et al..$^{52}$ (1993), demonstraram que a "smear layer" pode agir como uma barreira física, interferindo na adesão e penetração dos cimentos endodônticos no interior dos túbulos dentinários, e que sua permanência, a longo prazo, comprometeria o selamento apical, pois essa camada se solubilizaria, formando um espaço entre o material obturador e a parede do canal radicular.

Várias são as formas de remoção da "smear layer" da superfície do canal radicular, sendo o ácido etileno diamino tetraacético (EDTA), a substância mais amplamente utilizada. Além das substâncias químicas, e do ultra-som, a remoção da "smear layer" pelo uso dos lasers tem sido demonstrada por alguns autores $^{33}, 43,64,65$.

$O$ uso dos lasers em Endodontia, principalmente o Er:YAG e o Nd:YAG, tornou-se possivel com a introdução das fibras ópticas capazes de conduzir a energia emitida para o interior dos canais radiculares. As propriedades do laser Nd:YAG que permitem sua ampla utilização no tratamento do sistema de canais radiculares incluem a capacidade de evaporar tecido mole, provocar derretimento e fusão do tecido dentinário e ação antimicrobiana. 
DEDERICH; ZAKARIASEN; TULIP ${ }^{15}$, em 1984, foram os primeiros a observarem o derretimento e a fusão da dentina do canal radicular após a aplicação do laser Nd:YAG. Baseados na característica da parede do canal, observada por meio de microscopia eletrônica de varredura, os autores concluíram que a obliteração dos túbulos dentinários expostos poderia levar a uma diminuição da permeabilidade dentinária.

PARK ${ }^{55}$, em 2001, utilizaram o laser Nd:YAG anteriormente à obturação dos canais radiculares, e concluíram que os canais obturados, dessa forma, mostraram uma menor infiltração apical do que aqueles em que não foi utilizado o laser.

Além do preparo realizado anteriormente à obturação, o tipo de material obturador a ser utilizado é muito importante. A guta-percha, mundialmente difundida, não se adere às paredes dos canal radicular, sendo necessário a utilização de um cimento para o preenchimento de todo espaço anatômico do sistema de canais radiculares. A não utilização do cimento no momento da obturação, permite uma infiltração apical alta ${ }^{68}$. O tipo de cimento utilizado para obturação do canal radicular também irá influenciar no selamento apical, e vários são os trabalhos que mostram a superioridade dos cimentos resinosos para esse $\mathrm{fim}^{6,9,32}$.

Após a leitura de estudos que mostram a capacidade do laser $\mathrm{Nd}$ :YAG em derreter tecido dentinário, obliterando os túbulos, e diminuindo a permeabilidade da dentina, surgiu a dúvida de qual seria a melhor forma de se preparar a parede dentinária dos canais, anteriormente à obturação. A literatura é escassa no que diz respeito ao uso do laser Nd:YAG antes da obturação, principalmente em relação ao selamento apical propiciado por essa técnica. 


\section{REVISÃO DE LITERATURA}

Para melhor entendimento e facilidade de leitura, a revisão da literatura será abordada nos seguintes tópicos:

2.1) Ação do EDTA nas paredes dos canais radiculares.

2.2) Ação do laser Nd:YAG nas paredes dos canais radiculares.

2.3) Capacidade de selamento de cimentos endodônticos e técnicas obturadoras.

\section{1) Ação do EDTA nas paredes dos canais radiculares}

Dentre as etapas ou sequiências do tratamento endodôntico é de fundamental importância que a instrumentação dos canais radiculares seja coadjuvada com o uso de substâncias químicas, as quais facilitam este ato operatório, principalmente em canais atresiados, bem como, a utilização dessas substâncias na irrigação final para remoção da "smear layer" formada durante o preparo químico-cirúrgico.

CALLAHAN ${ }^{11}$, em 1894, foi o primeiro autor a sugerir o uso de um agente químico para facilitar a instrumentação de canais atresiados, preconizando o ácido sulfúrico a $40 \%$.

NIKIFORUK: SCREEBNY51, em 1953, demonstraram o efeito desmineralizador de um ácido fraco, o etilenodiaminotetracético (EDTA), um agente quelante em $\mathrm{pH}$ neutro verificando, também, que o efeito desmineralizador desse quelante era aumentado com a elevação da temperatura da solução. 
Em 1957, OSTBY ${ }^{54}$, propôs o uso do ácido etilenodiaminotetracético sal dissódico, em pH neutro como solução auxiliar de instrumentação de canais radiculares, principalmente nos mais atrésicos.

Von der FEHR; OSTBY ${ }^{21}$, em 1963, avaliaram, por meio de radiomicrografias, o efeito desmineralizador do EDTAC, em tempos diferentes, comparando-o com a solução de ácido sulfúrico. Para este estudo, foram utilizados 24 dentes que tiveram suas coroas removidas, e o tecido pulpar extirpado do interior do canal, o qual foi alargado de forma paralela a um diâmetro de 2 a 4 vezes maior que o inicial. Uma metade longitudinal dos canais foi recoberta com parafina servindo de controle e a outra ficou exposta para o contato com as soluções a serem testadas (metade experimental). Os ápices de todos os dentes foram recobertos com parafina e procedeu-se à aplicação do EDTAC em períodos de 5, 15 e 30 minutos, 24 e 48h e do ácido sulfúrico a 50\% em períodos de 5 e $15 \mathrm{~min}$. e $44 \mathrm{~h}$. Cortes transversais de todos os dentes, de aproximadamente 150 a 200 micrometros, foram realizados, sendo analisados, posteriormente no microscópio com $25 X$ de aumento. Os autores concluíram que - EDTAC teve um efeito desmineralizador rápido e limitado, e, quando utilizado por 5 minutos, foi capaz de quelar uma camada de dentina de 20 a 30 micrometros. Sua permanência por 48 horas resultou numa remoção completa dos sais minerais da parede dentinária numa profundidade de 50 micrometros. Já o ácido sulfúrico teve um efeito desmineralizador lento e incompleto, não agindo na remoção do cálcio e sim na conversão da hidroxiapatita em sulfato de cálcio.

FRASER ${ }^{23}$, em 1974, avaliou a capacidade de ação das soluções quelantes Decal, Largal Ultra e RC-Prep. Para este estudo foram utilizados 30 dentes anteriores humanos, divididos em 3 grupos de 10, que foram partidos no sentido vestíbulo-lingual, tendo suas polpas removidas e, então, escovados embaixo de água corrente. Uma metade de cada dente foi usada para se testar 
as soluções, enquanto a outra serviu de controle, recebendo apenas irrigação com água. Cada agente quelante ficou em contato com a dentina por 15 minutos $e$, após esse período, foi neutralizado com água. Em seguida, as duas metades das raízes foram unidas com parafina e incluídas em acrílico, para possibilitar um corte transversal em três porções, cervical, média e apical, afim de se avaliar a microdureza da dentina, nessas regiões. O autor concluiu que o Largal Ultra quelou a dentina mais do que o Decal e muito mais do que o RC-Prep, tanto no terço cervical quanto no médio e que nenhum dos agentes testados foi capaz de quelar a dentina do terço apical mais do que 20 micrometros.

GOLDBERG: ABRAMOVICH ${ }^{25}$, em 1977, analisaram a ação do EDTAC nas paredes dos canais radiculares de dentes humanos recém extraídos. Foram utilizados 6 incisivos superiores, que tiveram suas câmaras pulpares acessadas $e$ os canais radiculares instrumentados, irrigando-se com solução salina. Ao término da instrumentação, os dentes foram partidos ao meio, longitudinalmente, resultando em 12 metades, das quais 6 serviram de controle e as restantes foram imersas em solução de EDTAC por 15 minutos. No final deste período, renovou-se a solução e os espécimes ficaram imersos por mais 15 minutos na solução sendo, então, preparados junto com os espécimes controle para visualização no MEV. Os autores observaram que a superfície dentinária dos canais radiculares do grupo controle se apresentavam, geralmente, cobertas por uma camada amorfa ou granular, a qual recobria total ou parcialmente os túbulos dentinários, e esporadicamente, estava ausente. Na superfície dentinária dos canais radiculares tratados pela substância quelante, pode-se observar túbulos dentinários abertos, de aparência circular, separados por uma matriz intertubular.

RAM $^{59}$, em 1980, utilizando-se de microscopia eletrônica de varredura, avaliou a capacidade de limpeza e o efeito quelante de três 
substâncias químicas quando empregadas no interior dos canais radiculares, antes e após a instrumentação. Na primeira parte do trabalho, foram utilizados 8 dentes de cães, vitais, recém extraídos que foram partidos longitudinalmente, resultando em 16 metades, sendo 8 para o experimento e 8 reservadas para 0 controle. As polpas foram removidas $e$, com exceção das paredes dos canais radiculares, as demais superfícies foram cobertas com parafina. Em seguida, as 8 metades reservadas para o experimento foram dividas da seguinte maneira: grupo A - 1 metade imersa em água (controle); grupo B - 2 metades imersas em solução de EDTA à 15\%; grupo C - 2 metades imersas em RC-Prep; grupo D - 2 metades imersas em solução de Salvisol; grupo D" - 1 metade coberta por uma pasta de Salvisol. As 8 metades reservadas para o controle, foram imersas separadamente, em solução salina. Após 15 minutos de contato com as substâncias químicas, os espécimes foram lavados e preparados para análise ao MEV. Na segunda parte do trabalho, foram utilizados 5 dentes de cães, vitais, recém extraídos, que tiveram suas coroas eliminadas e foram divididos em 5 grupos, de acordo com a substância química auxiliar utilizada, na instrumentação dos canais: I - água; II - EDTA à 15\%; III - RC-Prep; IV - solução de Salvisol; V - pasta de Salvisol. Terminada a instrumentação, as raízes foram partidas longitudinalmente, resultando em 10 metades, sendo 5 para o experimento e 5 reservadas para o controle. Em seguida, com exceção das paredes dos canais radiculares, as demais superfícies foram cobertas com parafina e procedeu-se a imersão nas substâncias testadas, da mesma forma que na parte I do trabalho. Após análise no MEV, o autor concluiu que nos casos em que os canais não foram instrumentados, o Salvisol foi a substância que obteve o melhor resultado, ao passo que nos que tiveram os canais instrumentados, o EDTA foi a substância com maior capacidade de limpeza. 
BAUMGARTNER; MADER ${ }^{7}$, em 1987, avaliaram, através do microscópico eletrônico de varredura, as superfícies das paredes de canais radiculares instrumentados e não instrumentados, após o uso da solução salina a 0,09\%, hipoclorito de sódio a 5,25\%, EDTA 15\%, e da associação das duas últimas soluções citadas. Os autores chegaram as seguintes conclusões: 1 - todas as soluções testadas preveniram o acúmulo de raspas de dentina nas paredes dos canais radiculares; 2 - quando a solução salina ou hipoclorito de sódio foram usados como único irrigante, pôde-se observar a presença da "smear layer" nas paredes dos canais que foram instrumentados; 3 - quando o EDTA foi o único irrigante, a desmineralização da "smear layer" na parede do canal que foi instrumentado, ficou com um aspecto fibroso; 4 - quando a solução salina ou EDTA foram utilizados como únicos irrigantes, os restos pulpares e a pré-dentina da parede não instrumentada não foram removidos; 5 - quando o hipoclorito de sódio foi o único irrigante, os restos pulpares e a pré-dentina da parede não instrumentada foram removidos; 6 - quando o hipoclorito de sódio foi usado em combinação com o EDTA, os restos pulpares e a "smear layer" da parede do canal instrumentado foram completamente removidos, deixando uma superfície plana com túbulos dentinários abertos. Com essa mesma combinação, os restos pulpares e a pré-dentina da parede não instrumentada também foram removidos.

ZUOLO et $a^{78}$., em 1987, estudaram a ação do EDTA e suas associações com tensoativos aniônicos e catiônicos sobre a permeabilidade da dentina radicular. A mesma foi determinada por método histoquímico e quantificada pela análise morfométrica. Foram utilizados 25 incisivos centrais superiores humanos extraídos que foram impermeabilizados com parafina liquefeita e tiveram suas coroas removidas. As polpas radiculares foram removidas e a instrumentação realizada com auxílio das seguintes soluções: soro fisiológico (controle), EDTA 15\%, EDTAC (EDTA + Cetavlon), EDTAT (EDTA + 
Tergentol), EDTACP (EDTA associado ao Cloreto Cetil Piridino). Após o término da instrumentação efetuou-se irrigação com soro fisiológico e os canais foram secos para receberem os agentes químicos do ensaio histoquímico para verificação da permeabilidade. Com base na metodologia empregada, os autores concluíram que as soluções de EDTAC promoveram maior aumento da permeabilidade dentinária, a solução de EDTA ficou numa posição intermediária e - EDTACP, EDTAT e o soro fisiológico promoveram o menor aumento. Em relação às regiões dos canais em que as soluções mais atuaram, o terço cervical e médio apresentaram-se estatisticamente iguais e o terço apical apresentou-se menos permeável que os demais.

CIUCCHI; KHETTABI; HOLZ ${ }^{12}$, em 1989, compararam a capacidade de 4 substâncias na remoção da "smear layer" das paredes de canais mesiais de molares inferiores. Quarenta dentes foram utilizados e tiverem os canais instrumentados manualmente até a lima de $n^{\circ} 35$. A irrigação foi feita a cada troca de lima com a solução de hipoclorito de sódio a $3 \%$. Terminada a instrumentação, todos os canais foram irrigados com solução de hipoclorito de sódio e em seguida com água deionizada sendo, então, divididos em 4 grupos, de acordo com a técnica utilizada para remoção da "smear layer": I - controle (nenhuma solução utilizada); II - hipoclorito de sódio associado ao ultra-som por 2 min.; III - EDTA $15 \%$ por 3 min.; IV - EDTA $15 \%$ associado ao ultra-som por 2 min. Os autores concluíram que o hipoclorito de sódio e o EDTA, associados ou não ao ultra-som, não conseguiram remover completamente a "smear layer" do terço apical dos canais radiculares e que este fato se deve à dificuldade de difusão das soluções irrigadoras nessa região devido à mesma ser estreita $e$ curva. A remoção da "smear layer" nos três terços analisados foi mais efetiva no grupo III, seguido do IV, II e, por último, do I. 
GUTIERREZ et al. ${ }^{31}$, em 1990, avaliaram a ação de diferentes soluções irrigadoras na remoção da "smear layer" formada durante a instrumentação dos canais radiculares. Para este estudo foram utilizados 27 dentes distribuídos em 3 grupos: I - irrigação durante a instrumentação com hipoclorito de sódio a 5,25 \% alternado com peróxido de hidrogênio a 3\%; II irrigação durante a instrumentação com hipoclorito de sódio a 5,25 \% alternado com peróxido de hidrogênio a 3\% e irrigação final com EDTA $17 \%$ e solução de hipoclorito de sódio; III - irrigação durante a instrumentação com água destilada esterilizada durante a instrumentação e irrigação final com EDTA $17 \%$. Os autores concluíram que o grupo III foi o que se mostrou mais efetivo na remoção da "smear layer", seguido do grupo II e por último do grupo I.

TAKEDA ${ }^{66}$ et al., em 1999, avaliaram o efeito de três soluções irrigantes e dois tipos de laser, na remoção da "smear layer", do terço médio e apical, de canais radiculares instrumentados pela técnica manual. Utilizaram 60 dentes pré-molares inferiores humanos extraídos, que tiveram suas coroas removidas e canais radiculares instrumentados até a lima tipo $K n^{\circ} 60,1 \mathrm{~mm}$ aquém do forame apical. Ao final da instrumentação, os canais radiculares foram secos, e as raízes divididas em 5 grupos, de acordo com o preparo das paredes dos canais, da seguinte maneira: I - EDTA a 17\% durante 5 minutos; II - ácido fosfórico a $6 \%$ durante 5 minutos; III - ácido fosfórico a $6 \%$ durante 5 minutos e irrigação com ácido cítrico a $6 \%$; IV - laser $\mathrm{CO}_{2} ; \mathrm{V}$ - laser Er:YAG. Em seguida, as raízes foram partidas longitudinalmente, e preparadas para exame ao M.E.V. Os autores concluíram que os grupos II e III, apresentaram as paredes dos canais nos terços médio e cervical mais limpas que o grupo I, porém a "smear layer" do terço apical dos três grupos não foi completamente removida. No grupo IV, as paredes dos canais ficaram livres da "smear layer", ou a mesma se apresentou derretida, recristalizada e vitrificada, tanto no terço apical quanto 
no médio e cervical. No grupo $V$, onde foi usado o laser Er:YAG, as paredes dos canais ficaram livres da "smear layer", com túbulos dentinários abertos no terços apical, médio e cervical, sendo o mais eficaz método de remoção da "smear layer", dos abordados nesse estudo.

RIBEIRO: MEDINA; MORAES ${ }^{60}$, em 2001, avaliaram a infiltração marginal apical em obturações de canais após a utilização de diferentes soluções irrigadoras. Utilizou-se 40 incisivos extraídos, cujas coroas foram removidas e os dentes divididos em 4 grupos de 10 de acordo com as soluções utilizadas na instrumentação: EDTA, ácido cítrico 10\%, clorexidina 2\% e Endoquil. Terminada a instrumentação com padronização dos forames, foi realizada a impermeabilização da superfície externa da raiz, exceto o forame apical, e em seguida os canais foram obturados pela técnica da condensação lateral e cimento endomethasone. $\mathrm{Na}$ sequência, as raízes foram imersas em solução de azul de metileno a $2 \%$ por $72 \mathrm{~h}$ a $37^{\circ} \mathrm{C}$. Os resultados mostraram não haver diferença estatística significante entre os grupos, mas numericamente observou-se a seguinte ordem crescente de infiltração: Endoquil, ácido cítrico 10\%, clorexidina 2\% e EDTA.

PASSARINHO NETO et al..$^{56}$, em 2001, avaliaram o efeito das soluções quelantes EDTA C e EDTA T sobre as paredes dos canais radiculares. Foram utilizados 32 caninos superiores extraídos, que tiveram seus canais instrumentados e, em seguida, foram divididos em 4 grupos para receber $2 \mathrm{ml}$ de uma das soluções testadas, as quais permaneceram em contato com a dentina durante 5 minutos. Após a irrigação final, os canais foram secos e obturados com guta-percha e cimentos Sealer 26 e de Grossman. Logo em seguida, os dentes foram imersos em tinta nanquim e submetidos à diafanização para medição da infiltração marginal. Os resultados demonstraram haver diferença estatística significante a nivel de $1 \%$ entre as soluções testadas, de forma que o EDTAC 
diminuiu os índices de infiltração marginal nos canais obturados tanto com cimento Sealer 26 como com o cimento de Grossman.

OLIVEIRA et al. ${ }^{53}$, em 2001, avaliaram in vitro, através do MEV, a ação de diferentes soluções irrigadoras na remoção da "smear layer" dos canais radiculares. Foram utilizados 25 dentes humanos unirradiculados, distribuídos aleatoriamente em 4 grupos: Grupo I- EDTA 17\%; Grupo II - hipoclorito de sódio a 5,25\%; GrupoIII - Endoquil; Grupo IV - gel de Natrosol; Grupo V - água destilada (grupo controle). Os resultados mostraram diferença estatisticamente significante entre o grupo controle e o hipoclorito de sódio a $5,25 \%$. Os grupos do EDTA 17\%, gel de Natrosol e Endoquil não apresentaram diferença estatisticamente significante, obtendo maior capacidade de limpeza quando comparados com os dois primeiros grupos.

COSTA; SCELZA; SCELZA ${ }^{13}$, em 2001 avaliaram a capacidade de remoção da "smear layer" das paredes dentinárias pelas substâncias EDTA 17\% e ácido cítrico a 10\% em três diferentes tempos de irrigação. Foram utilizados 30 dentes unirradiculados humanos que tiveram seus canais instrumentados $e$ irrigados com hipoclorito de sódio 5\%, e em seguida, distribuídos em 6 grupos de 5 elementos para receberem irrigação final com as seguintes soluções: Grupo I ácido cítrico por 3 minutos; Grupo II - ácido cítrico por 10 minutos Grupo III ácido cítrico por 15 minutos; Grupo IV - EDTA por 3 minutos; Grupo V - EDTA por 10 minutos; GrupoVI - EDTA por 15 minutos. Em seguida os dentes foram clivados e preparados para exame no MEV. Os autores concluíram que o ácido cítrico no tempo de 3 minutos foi mais eficaz na remoção da "smear layer" que o EDTA no mesmo tempo, ao passo que o EDTA foi mais eficaz que o ácido cítrico nos tempos de 10 e 15 minutos, porém essas diferenças não foram estatisticamente significantes. 


\section{2) Ação do laser $N d: Y A G$ nas paredes dos canais radiculares}

A palavra laser é uma abreviatura para Light Amplification by Stimulated Emission of Radiation. Os princípios que guiaram seu desenvolvimento foram propostos por EISTEIN ${ }^{19}$ em 1917, quando descreveu o terceiro processo de integração da matéria: a emissão estimulada da radiação. $O$ autor observou que se um átomo de determinado tamanho, incidir numa molécula num estado excitado, essa molécula retornaria para um nível menor de energia e emitiria um átomo exatamente do mesmo tamanho, e na mesma direção do átomo que incidiu na molécula inicialmente.

Contudo, a primeira aplicação com sucesso da amplificação de microondas, pela emissão estimulada da radiação (MASER), foi relatada por GORDON: ZEIGLER; TOWNES ${ }^{26}$, em 1955, de forma que o MASER poderia ser aplicado a ondas eletromagnéticas, de qualquer comprimento de onda, incluindo a luz.

Em 1958, SCHAWLON: TOWNES ${ }^{61}$, colocaram em prática essa possibilidade, chamando esse processo de LASER.

O primeiro raio laser foi obtido por MAIMAN ${ }^{41}$, em 1960, através da emissão estimulada de radiação, no espectro visível, a partir da excitação de um cristal de rubi.

Em 1961, JOHNSON ${ }^{35}$, desenvolveu o laser Nd:YAG, a partir da interação de íons neodímio com os cristais de ítrio, alumínio e granada. O laser tem comprimento de onda de 1,06 nm, invisível, e é absorvido preferencialmente por tecidos pigmentados.

O laser foi utilizado pela primeira vez na endodontia por WEICHMAN: JOHNSON ${ }^{70}$, em 1971, os quais tentaram selar externamente o forame apical de dentes humanos extraídos com o laser $\mathrm{CO}_{2}$. Os autores 
observaram na região do ápice de alguns dentes, derretimento do cemento e da dentina, formando um capuz que, no entanto, era facilmente deslocado ao toque, indicando a falta de fusão entre o capuz e a estrutura dentária adjacente.

Posteriormente, em 1972, WEICHMAN: JOHNSON: NITTA ${ }^{71}$ tiveram como propósito, selar internamente o forame apical, com a colocação de alguns materiais fundentes, entre eles, pó de dentina, pó de esmalte, hipoclorito de sódio, e posterior aplicação do laser $\mathrm{CO}_{2}$ e $\mathrm{Nd}$ :YAG. Os resultados obtidos foram parecidos com o estudo anteriormente realizado, observando-se um derretimento da dentina, com formação eventual de um capuz, descontínuo com a dentina adjacente que não foi irradiada. Não houve diferença entre a utilização do laser $\mathrm{CO}_{2}$ e Nd:YAG para os materiais testados. Quando o material a ser fundido era líquido, nenhuma mudança ocorria na dentina até que o líquido evaporasse. $O$ efeito do laser nos materiais em forma de pó variou de uma queima até um ligeiro derretimento.

DEDERICH: ZAKARIASEN: TULIP ${ }^{15}$, em 1984, avaliaram o efeito do laser $\mathrm{Nd}$ YYAG na dentina, utlizando-se do microscópio eletrônico de varredura. Cinco caninos humanos extraídos foram cortados no sentido vestíbulolingual e concavidades foram feitas ao longo do canal radicular, com broca tipo cone invertido. Essas pequenas concavidades, com "smear layer" na superfície, serviram de local para irradiação do laser por meio de uma fibra de quartzo de 600 micrometros, variando a potência de 10 a $90 \mathrm{~W}$ e o tempo de 0.1 a 0.9 s. Os autores observaram que a "smear layer" irradiada pelo laser se apresentou intacta em alguns casos, e em outros, derretida e recristalizada, de aparência lisa, sem porosidades.

ZAKARIASEN: DEDERICH: TULIP ${ }^{74}$, em 1985, realizaram estudo para avaliar a capacidade dos lasers $\mathrm{Nd}: \mathrm{YAG}$ e $\mathrm{CO}_{2}$, em fusionar pó de dentina com a superfície dentinária do canal radicular. Para a aplicação do laser de $\mathrm{CO}_{2}$, 
foram clivados alguns dentes e feitos preparos na parede do canal radicular, onde eram acomodadas as partículas de dentina para posterior irradiação. A análise ao MEV, mostrou áreas, onde a parede dentinária do canal radicular se fusionou com o pó de dentina, formando uma massa contínua, não porosa. Em algumas áreas, rachaduras, falhas e uma fusão incompleta pôde ser observada. Para o uso do laser Nd:YAG, as partículas de dentina foram assentadas a $1 \mathrm{~mm}$ do forame apical, e a energia foi conduzida até essa região por meio de uma fibra óptica de 600 micrometros, via canal radicular, que no momento da irradiação ficou a uma distância de $3 \mathrm{~mm}$ do pó de dentina. O parâmetro utilizado foi de 25 , 37 e $50 \mathrm{~W}$ por 0,5s. A análise ao MEV, revelou uma fusão e recristalização entre o pó de dentina e a superfície dentinária do canal radicular, formando uma massa contínua, não porosa. Entretanto, alguns espécimes mostraram pequenas falhas nessa fusão com aparecimento de rachaduras ocasionadas pelo efeito térmico do laser.

ZAKARIASEN; DEDERICH; TULIP75, ainda em 1985, utilizando-se de microscopia eletrônica de varredura, analisaram as características da parede do canal radicular após a aplicação do laser Nd: YAG. Utilizaram 18 dentes unirradiculados, que foram partidos longitudinalmente, $e$ ao longo do canal radicular foram feitas concavidades, que, posteriormente foram pintadas com tinta nanquim, posteriormente, para que servissem como áreas de exposição ao raio laser. As exposições variaram em potências de 5 a $90 \mathrm{~W}$, e em tempos, de 0.1 a 1segundo. Ao M.E.V., avaliou-se a presença de rachaduras e o grau de fusão dos tecidos irradiados, de acordo com a potência e tempo utilizados. Os autores concluíram que quando a potência e a duração do pulso foram consideradas isoladamente, influenciaram na quantidade de rachaduras presente nas concavidades. Por outro lado, quando consideradas juntas, influenciaram de uma forma mais significativa no aparecimento de rachaduras. 
STABHOLZ et al. ${ }^{63}$, em 1992, tiveram como objetivo investigar o efeito do laser Nd:YAG na permeabilidade dentinária após apicetomia $e$ retroobturação com amálgama. As superfícies dentinárias apicetomizadas e algumas cavidades retrógradas foram irradiadas pelo laser Nd:YAG em dois diferentes estágios: no primeiro, utilizando-se $3 W$ de potência e $150 \mathrm{mj} /$ pulso de energia sem irrigação, e no segundo, 1,9W de potência e $95 \mathrm{mj} /$ pulso de energia com irrigação, ambos com $20 \mathrm{~Hz}$ de freqüência. Após o preenchimento das cavidades retrógradas com amálgama, os espécimes foram impermeabilizados e imersos em solução de azul de metileno a $0,5 \%$. Os resultados mostraram que a penetração de corante foi significativamente menor nos espécimes que foram irradiados pelo laser, levando os autores à conclusão de que a aplicação do laser Nd:YAG diminuiu a permeabilidade dentinária das superfícies apicetomizadas.

WIGDOR et al. ${ }^{72}$, em 1993, avaliaram o efeito de três tipos de laser, $\mathrm{CO}_{2}, \mathrm{Nd}: Y A G$ e Er:YAG na superfície dentinária de dentes humanos extraídos e de dentes de cães, não extraídos. Tanto para o estudo in vitro como in vivo, foram feitas pequenas janelas no esmalte, na superfície vestibular dos dentes, expondo uma área de dentina de aproximadamente $3 \mathrm{~mm}$ de diâmetro e 2 $\mathrm{mm}$ de profundidade. Pela análise ao M.E.V, os autores concluíram que o laser Er:YAG, no estudo in vitro, quando comparado com os outros tipos de laser $e$ com o grupo controle (dentina não irradiada), causou menor efeito na superfície dentinária, a qual se mostrou bem definida. Já o laser $\mathrm{CO}_{2}$ e Nd:YAG, foram os que causaram uma maior modificação na dentina, a qual se mostrou com túbulos dentinários pouco evidentes, dentina inter-tubular derretida, e presença de rachaduras. Histologicamente, nos dentes de cães, em relação aos dentes irradiados pelo laser Nd:YAG, pôde-se observar a destruição da camada odontoblástica e a presença de um infiltrado inflamatório, caracterizando uma pulpite irreversivel com provável evolução para uma necrose do tecido pulpar. Os 
dentes irradiados pelo laser Er:YAG, mostraram uma camada odontoblástica organizada, com vascularização e celularidade similar ao tecido conjuntivo do grupo controle (não irradiado), sem presença de infiltrado inflamatório. Os dentes irradiados pelo laser $\mathrm{CO}_{2}$ apresentaram perda da camada odontoblástica e da pré-dentina, e presença de um exudato inflamatório.

$O$ efeito do laser Nd:YAG, na permeabilidade dentinária e nas características das paredes dos canais radiculares, foi avaliado por MISERENDINO: LEVY: RIZOIU ${ }^{49}$, em 1995. Vinte dentes humanos extraídos tiveram seus canais instrumentados sendo, então, divididos em 2 grupos: grupo I - canais não irradiados; grupo II - canais receberam 3 ciclos de 15s de exposição ao raio laser, por uma fibra óptica, totalizando 45 s de exposição. Os parâmetros do laser foram $5 \mathrm{~W}$ e $50 \mathrm{~Hz}$, com irrigação e ar sob pressão simultaneamente. $O$ uso combinado da microscopia eletrônica de varredura com o teste de permeabilidade revelou uma obliteração dos túbulos dentinários por um material parecido com vidro $e$, em um dos casos puderam observar a obliteração de um canal lateral por esse material. A permeabilidade dentinária dos dentes tratados com o laser foi significativamente menor do que a dos dentes não tratados.

ANIC: TACHIBANA: MASUMOTO ${ }^{3}$, em 1996, avaliaram as diferenças na permeabilidade dentinária das paredes dos canais radiculares, com e sem "smear layer", após irradiação com o laser $\mathrm{Nd} Y \mathrm{YAG}, \mathrm{CO}_{2}$ e Argon. A temperatura da superfície radicular e as mudanças morfológicas da "smear layer" e da superfície dentinária também foram avaliadas nesse estudo. A energia do laser foi conduzida para o interior dos canais radiculares por intermédio de uma fibra óptica flexível, ou por meio de uma ponta metálica, variando-se potência, tempo e quantidade de pulsos por segundo para cada tipo de laser. Os autores concluíram que apenas no terço apical dos canais irradiados com o laser $\mathrm{Nd}$ :YAG e $\mathrm{CO}_{2}$, houve uma redução estatisticamente significante da 
permeabilidade dentinária quando comparado com o grupo controle. Em relação às características morfológicas das paredes do canal radicular, a superfície dentinária do terço apical com ou sem "smear layer", irradiada pelo laser Nd:YAG, mostrou-se com aspecto derretido. Já o terço médio dos canais, sem "smear layer", irradiados pelo laser Nd:YAG, mostraram superfície dentinária derretida e recristalizada, mas túbulos dentinários abertos eram facilmente observados. A temperatura mais elevada foi produzida pelo laser argon, seguido pelo $\mathrm{Nd}$ :YAG e $\mathrm{CO}_{2}$.

ANIC et al. ${ }^{4}$, em 1998, tiveram como propósito comparar as mudanças na morfologia das superfícies dentinárias, quando estas fossem irradiadas pelo laser de forma perpendicular ou paralela. Foram utilizados os laser $\mathrm{Nd}: \mathrm{YAG}, \mathrm{CO}_{2}$ e Argon, que foram aplicados em finas fatias de dentina e no interior dos canais radiculares. Quando o raio laser foi utilizado paralelo à superfície dentinária, os resultados variaram desde nenhum efeito até uma "smear layer" derretida e recristalizada, ao passo que quando utilizado perpendicularmente à superfície dentinária, todos os três lasers produziram crateras. Quando utilizado de forma paralela, o laser Nd:YAG produziu mais efeito quando comparado com os outros dois tipos de laser.

ZHANG et al. ${ }^{76}$, em 1998, avaliaram o efeito do laser Nd:YAG sobre a permebilidade dentinária, de canais radiculares, quando da utilização de substâncias potencializadoras ou não. Quarenta dentes unirradiculados humanos tiveram seus canais radiculares instrumentados, e em seguida, foram divididos em 4 grupos de 10 da seguinte maneira: grupo I - controle; grupo II - canais irradiados pelo laser com irrigação; grupo III - tinta nanquim preta colocada até o comprimento de trabalho e em seguida uso do laser como no grupo II; grupo IV - $\mathrm{Ag}\left(\mathrm{NH}_{3}\right)_{2} \mathrm{~F}$ a $38 \%$ colocado até o comprimento de trabalho e em seguida uso do laser como no grupo II. Os parâmetros utilizados para a aplicação do laser 
Nd:YAG foram de $2 W$ e 20 pps. Uma fibra de 320 micrometros era introduzida no limite apical, e então, o laser era acionado, realizando-se um movimento vertical de pequena amplitude, com a fibra óptica, durante 10 segundos. Essa irradiação pelo laser era repetida 4 vezes, totalizando tempo de exposição de 40 segundos por canal. O teste de infiltração apical pela rodamina $B$ a $0,6 \%$ mostrou uma diferença estatística significante entre os grupos III - I, IV - I, e IV - II. Ainda em relação ao teste de infiltração apical, o grupo IV foi o que apresentou menor infiltração, seguido dos grupos III, II e I. Sete dentes de cada grupo foram preparados para estudo por meio do M.E.V. Os autores concluíram que as paredes dos canais radiculares do grupo II se mostraram ao exame no M.E.V., com presença da "smear layer" na maioria dos casos. Em poucos casos houve uma evaporação da "smear layer", expondo túbulos dentinários. No grupo III, em que foi usada a tinta nanquim, a "smear layer" das paredes dos canais radiculares foi evaporada ou derretida, expondo os túbulos dentinários ou obliterando-os. $O$ mesmo ocorreu para o grupo IV onde se utilizou a $\mathrm{Ag}\left(\mathrm{NH}_{3}\right)_{2} \mathrm{~F}$ a $38 \%$ como substância potencializadora.

GOYA et al. ${ }^{27}$, em 2000, tiveram como objetivo avaliar a remoção da "smear layer" pelo laser Nd:YAG, quando da utilização de tinta nanquim ou não, e a infiltração apical após a obturação do sistema de canais radiculares. Sessenta dentes unirradiculados humanos extraídos tiveram suas coroas cortadas na junção cemento-esmalte, em seguida os canais radiculares foram instrumentados, e submetidos a uma irrigação final com EDTA a $14 \%$, sendo então divididos em três grupos de 20 dentes da seguinte maneira: grupo I controle; grupo II - canais irradiados pelo laser; III - canais pigmentados com tinta nanquim preta e em seguida irradiados pelo laser. Os parâmetros utilizados para o laser foram os mesmos para os dois grupos: $2 \mathrm{~W}, 100 \mathrm{~mJ}$ e $20 \mathrm{~Hz}$. A fibra óptica era introduzida no comprimento de trabalho, o laser ativado por 2 
segundos, e em seguida, era feito um intervalo de 30 segundos. Ao fim do intervalo, o laser era aplicado mais uma vez, totalizando 4 segundos de aplicação. Dez dentes foram partidos longitudinalmente e preparados para análise ao M.E.V. Os resultados revelaram que as paredes dos canais radiculares do grupo I estavam cobertas pela "smear layer", com ausência de túbulos dentinários expostos, na maioria dos espécimes. No grupo II, as paredes dos canais radiculares apresentaram túbulos dentinários abertos com superfície dentinária derretida. Já no grupo III, onde se utilizou a tinta nanquim previamente ao laser, parte da "smear layer" evaporou, exibindo superfícies com túbulos dentinários abertos e outra parte derreteu e se aderiu à dentina, obliterando os túbulos dentinários. Para a segunda etapa do estudo, os dez dentes restantes de cada grupo tiveram seus canais obturados pela técnica da condensação lateral, e as raízes impermeabilizadas externamente, exceto o forame apical, para então, serem imersas em solução de rodamina $B$ a $0,6 \%$. A penetração do corante foi observada em $60 \%$ das amostras do grupo I, $20 \%$ das amostras do grupo II e em nenhuma amostra do grupo III, levando os autores a concluírem que a irradiação com o laser associada à tinta nanquim reduziu de forma significativa a infiltração apical.

TURKMEN et al. ${ }^{69}$, em 2000, compararam o efeito do laser $\mathrm{CO}_{2}$, Nd:YAG e ArF excimer na dentina e no aumento da temperatura na câmara pulpar. Sessenta e seis molares humanos extraídos tiveram a câmara pulpar acessada e a polpa coronária removida, para, então, serem submetidos à aplicação dos diferentes tipos de laser nos seguintes parâmetros: $3 W$ e 20 pps durante 30 segundos. $O$ aumento da temperatura interna na câmara pulpar foi de $37^{\circ} \mathrm{C}$ (laser $\mathrm{CO}_{2}$ ), $28^{\circ} \mathrm{C}$ (laser $\mathrm{Nd} ; \mathrm{YAG}$ ) e $1^{\circ} \mathrm{C}$ (laser ArF excimer). $\mathrm{O}$ exame ao M.E.V., mostrou uma superfície dentinária irradiada pelo laser Nd:YAG com ausência de túbulos dentinários expostos, de característica esponjosa e uma "smear layer" 
desarranjada apresentando algumas fissuras. No grupo irradiado pelo laser $\mathrm{CO}_{2}$, os autores observaram derretimento e recristalização da dentina, e dentina intertubular desmineralizada. O grupo irradiado pelo laser ArF excimer, mostrou uma dentina com túbulos dentinários obliterados e dentina intertubular bem delimitada.

BEZERRA: ARAKI; CALDEIRA ${ }^{8}$, em 2001, analisaram o selamento marginal apical de canais radiculares obturados com o cimento AH Plus, após irradiação pelo laser Er:YAG, Nd:YAG e associação de ambos. Foram utilizadas 36 raízes de dentes unirradiculados humanos, que tiveram seus canais instrumentados com o sistema Profile até instrumento \# 40, e em seguida divididos em 4 grupos de acordo com o preparo a ser realizado na superfície dentinária do canal radicular: grupo I - irradiado com o laser Er:YAG; grupo II irradiado com o laser Nd:YAG; grupo III - irradiado com o laser Er:YAG seguido do laser Nd:YAG; grupo IV - não foi irradiado. Em seguida, os canais foram obturados e os espécimes preparados para imersão em solução de azul de metileno a $0,5 \%$. Após a análise dos dados, os autores concluíram não existir diferenças estatisticamente significantes entre os diferentes grupos, evidenciando a não influência do laser na qualidade do selamento para essa hipótese experimental.

PARK et al. ${ }^{55}$, em 2001, avaliaram o efeito do laser Nd:YAG na infiltração apical de canais radiculares obturados, por meio do estudo eletroquímico. Quarenta dentes unirradiculados humanos extraídos tiveram suas coroas removidas e foram divididos em 4 grupos de 10 da seguinte maneira: grupo I - os canais foram instrumentados pela técnica step-back, irradiados pelo laser e obturados pela técnica da condensação lateral utilizando o cimento Pulp Canal Sealer EWT; grupo II - procedeu-se igual ao grupo I, sem o uso do laser: grupo III - os canais foram instrumentados pelo sistema ProFile 06., irradiados 
pelo laser e obturados pela técnica da condensação vertical da guta-percha utilizando o cimento Pulp Canal Sealer EWT; grupo IV - procedeu-se igual ao grupo III, sem o uso do laser. Os parâmetros utilizados para a aplicação do laser foi de $5 \mathrm{~W}$ e $20 \mathrm{~Hz}$ através de uma fibra óptica de 300 micrometros. A fibra era introduzida a $1 \mathrm{~mm}$ do ápice radicular e durante a ativação era retirada num tempo total de exposição de 3 segundos por canal. Após análise dos resultados, os autores concluíram que o grupo IV foi o que apresentou maior média de infiltração, seguido dos grupos II, I e III.

Em 2002, PICOCOLOMIMI et al. ${ }^{57}$, tiveram como objetivo avaliar a eficiência do laser Nd:YAG em esterilizar canais radiculares contaminados com Actinomyces naeslundii e Pseudomonas aeriginosa, quando utilizado em dois parâmetros diferentes, $5 \mathrm{~Hz}$ ou $10 \mathrm{~Hz}$ de frequência para 15 segundos de exposição. Sessenta dentes foram divididos em 2 grupos de 30 de acordo com o tipo bacteriano, e esses, divididos em 3 subgrupos de 10, de acordo com o tipo de tratamento do canal radicular: Grupo A1 - sem tratamento; Grupo B1 - laser à $5 \mathrm{~Hz}$; Grupo $\mathrm{C1}$ - hipoclorito de sódio 5,25\%; Grupo A2 - sem tratamento; Grupo B2 - laser à $10 \mathrm{~Hz}$; Grupo $\mathrm{C2}$ - hipoclorito de sódio 5,25\%. Os resultados indicaram que com o uso do laser a $5 \mathrm{~Hz} / 15$ s, houve uma diminuição de $34 \%$ CFU para as bactérias Actinomyces naeslundii e de $15,7 \%$ CFU para as Pseudomonas aeriginosa, ao passo que com o uso do laser a $10 \mathrm{~Hz} / 15 \mathrm{~s}$, houve uma diminuição $77,4 \%$ CFU para as bactérias Actinomyces naeslundii e de $85,8 \%$ CFU para as Pseudomonas aeriginosa. Nenhuma bactéria foi encontrada quando foi utilizado o hipoclorito de sódio a 5,25\% como substância irrigadora. 


\section{3) Capacidade de selamento de cimentos endodônticos e técnicas obturadoras.}

Em 1958, GROSSMAN ${ }^{28}$ propôs um cimento para uso em conjunto com a guta-percha ou cone de prata na obturação dos canais radiculares. $O$ cimento era à base de óxido de zinco e eugenol, não possuía prata precipitada e tinha como propriedades físicas, plasticidade, adesividade, radiopacidade $e$ consistência macia.

GROSSMAN ${ }^{30}$, em 1978, avaliou a solubilidade dos cimentos AH 26, Diaket, Tubli seal, Proco-sol, Kerr, Roth 801, Roth 811, Mynol, óxido de zinco e eugenol e N2. Tubos metálicos foram preenchidos pelos cimentos a serem testados, e em seguida, colocados em um incubador a $37^{\circ} \mathrm{C}$, para que ocorresse a presa dos cimentos. No dia seguinte, os tubos foram pesados, e então, imersos em solução composta de $98 \%$ de água deionizada e duas partes de caldo nutriente por uma semana, para simular o exudato periapical. Decorrido este período, os tubos foram pesados novamente, de forma que a perda do peso foi considerada 0 grau de solubilidade. Os resultados apontaram que O AH 26 e o Diaket apresentaram o menor grau de solubilidade, enquanto que os cimentos derivados do óxido de zinco e eugenol apresentaram solubilidade variada.

ALEXANDER; GORDON ${ }^{1}$, em 1985, compararam o selamento apical proporcionado pelos cimentos Sealapex, CRCS e de Grossman. Utilizaram 30 incisivos superiores humanos, que tiveram suas coroas removidas e seus canais instrumentados até a lima tipo K 60, e em seguida foram divididos em 3 grupos de 10, de acordo com o cimento utilizado na obturação, realizada pela técnica da condensação lateral. Após impermeabilização, as raízes foram imersas em solução de azul de metileno a $2 \%$ a $37^{\circ} \mathrm{C}$, durante 6 dias. Os autores concluíram que o Sealapex $e$ o cimento de Grossman promoveram médias de infiltração apical 
próximas, 0.58 e 0.95 , respectivamente, bem menores do que a do cimento CRCS (2.72).

SPERBECK: SCOTT ${ }^{62}$, em 1993, compararam o selamento apical em canais obturados pela técnica da condensação lateral com cimento de Grossman e técnica do cone único utilizando o cimento de ionômero de vidro. Foram utilizados 24 dentes anteriores humanos extraídos, que tiveram seus canais instrumentados e em seguida foram divididos em 2 grupos, de acordo com a técnica de obturação e cimento utilizados. Realizada a obturação dos canais, as raízes ficaram por $48 \mathrm{~h}$ em temperatura ambiente, para que ocorresse a presa do cimento, e em seguida foram imersos em solução de azul de metileno a $1 \%$ a $37^{\circ} \mathrm{C}$ por 7 dias. Os resultados indicaram, que os canais obturados com o cimento de ionômero de vidro pela técnica do cone único, tiveram um valor médio de infiltração apical (2.22), bem menor, do que os canais obturados pelo cimento de Grossman (3.63) utilizando-se da técnica da condensação lateral.

ESTRELA et al. ${ }^{20}$, em 1994, compararam o selamento apical em canais obturados com os cimentos Fillcanal, N-Rickert, Sealapex e AH-26, por duas diferentes técnicas de obturação, condensação lateral passiva e ativa. Foram utilizados 80 incisivos centrais superiores humanos extraídos, que tiveram seus canais instrumentados e em seguida irrigados com EDTA trissódico por 5 minutos, sendo, então, divididos em 4 grupos de 20 de acordo com o cimento utilizado. Os autores concluíram que todos os cimentos utilizados permitiram uma infiltração apical e que não houve diferença estatística significante entre os mesmos, independente da técnica utilizada. Quando comparada a infiltração apical entre as técnicas de obturação, todos os cimentos, exceto o N-Rickert, apresentaram diferença estatística significante, com menores valores de infiltração para a técnica da condensação lateral ativa. $O$ cimento obturador $N$ - 
Rickert apresentou a mesma capacidade de selamento quando utilizado com ambas as técnicas.

KOCH: MIN; STEWART ${ }^{38}$, em 1994, avaliaram a capacidade seladora apical dos cimentos Ketac-Endo e de Grossman. Utilizaram 48 dentes humanos unirradiculados extraídos, que tiveram suas coroas removidas e canais instrumentados até lima tipo K 40 no limite de trabalho. Em seguida, os dentes foram distribuídos em grupos de acordo com a técnica de obturação e cimentos utilizados: grupo I - técnica do cone único e cimento de Grossman; grupo II condensação lateral e cimento de Grossman; grupo III - técnica do cone único e cimento Ketac-Endo; grupo IV - condensação lateral e cimento Ketac-Endo. Os dentes foram armazenados numa câmara com $100 \%$ de umidade durante 7 dias para permitir o endurecimento dos cimentos. Ao final desse tempo, as superfícies externas das raízes foram impermeabilizadas, e imersas em tinta nanquim por 10 dias. Após análise da penetração do corante nas obturações, os autores concluíram que os grupos III e IV tiveram menores médias de infiltração que os grupos I e II, sendo que o grupo IV foi o que apresentou melhor resultado.

FIDEL et al. ${ }^{22}$, em 1994, avaliaram a capacidade de adesão à dentina, dos cimentos Sealer 26, CRCS, Fillcanal, Sealapex e Apexit, com e sem a presença da "smear layer". Os autores concluíram que o CRCS foi o cimento com maior poder de adesão à dentina na presença da "smear layer". Nessa mesma situação, o Fillcanal e o Sealapex tiveram resultados similares, com maior poder de adesão que o Apexit e menor que o Sealer 26. Na ausência da "smear layer", o cimento com maior poder de adesão foi o Sealer 26, seguido dos cimentos CRCS, Fillcanal, Sealapex e Apexit.

ZMENER et al. ${ }^{77}$, em 1997, avaliaram o selamento apical proporcionado pelos cimentos $A H$ Plus e $A H$ 26, através da penetração do 
corante azul de metileno a 5\%, no período de 2, 4 e 10 dias. Os canais foram obturados pela técnica da condensação lateral e a extensão de penetração do corante foi medida por um microscópio estereoscópico. No período de 2 dias, os autores observaram nos canais obturados pelo cimento $A H 26$, uma extensão de penetração do corante de $0.4 \mathrm{~mm}$, e para o AH Plus, $1.4 \mathrm{~mm}$. A infiltração apical, quando observada nos períodos posteriores, aumentou de forma significante, assim como, a diferença entre os cimentos testados, tendo o AH 26 os melhores resultados.

ECONOMIDES et al. ${ }^{18}$, em 1999, examinaram o efeito da "smear layer" na microinfiltração apical num período de 16 semanas. Foram utilizados 104 dentes unirradiculados humanos, que tiveram suas coroas removidas e canais radiculares instrumentados, e em seguida divididos em 4 grupos da seguinte maneira: I - permanência da "smear layer" e obturação com o cimento Roth 811; II - permanência da "smear layer" e obturação com o cimento AH 26; III remoção da "smear layer"e obturação com o cimento Roth 811; IV - remoção da "smear layer" e obturação com o cimento AH 26. A infiltração apical foi medida pelo método eletroquímico, e os resultados indicaram que a remoção da "smear layer" resultou numa redução estatisticamente significante da infiltração apical nos canais obturados pelo cimento AH 26. A presença ou ausência da "smear layer" não teve efeito significante na infiltração apical nos canais obturados pelo cimento Roth 811.

HAIKEL et al. ${ }^{32}$, em 1999, avaliaram a capacidade de selamento apical oferecida pelos cimentos Sealapex, AH Plus e Sealite. Utilizaram 113 dentes humanos extraídos, que tiveram seus canais instrumentados sendo, então, divididos em três grupos: I - controle negativo (4 dentes); II - canais de 105 dentes, divididos proporcionalmente, foram obturados pela técnica da condensação lateral com os três cimentos testados; III - controle positivo (4 
dentes). Em seguida, os grupos foram imersos em solução de lisozima I-125, por períodos de 1, 7, 14 ou 28 dias. Ao final dos períodos, os autores concluíram que os canais obturados com o AH Plus e o Sealapex tiveram menores médias de infiltração apical, apresentando melhores resultados o cimento AH Plus. Os canais obturados pelo Sealite apresentaram a maior média de infiltração.

MILETIC et al. ${ }^{48}$, no mesmo ano, avaliaram o selamento apical proporcionado pelos cimentos AH26, AH Plus, Diaket, Apexit e Ketac-Endo. Sessenta dentes unirradiculados humanos extraídos tiveram suas coroas e $3 \mathrm{~mm}$ apicais das raízes removidos. Os canais foram instrumentados pela técnica "stepback" e em seguida as raízes foram divididas em grupos, de acordo com o cimento utilizado para obturação dos canais radiculares, pela técnica da condensação lateral. A infiltração apical foi medida pelo modelo de transporte de fluidos, e concluiu-se que não houve diferença estatística significante entre os grupos estudados.

ALMEIDA et al. ${ }^{2}$, em 2000, avaliaram a capacidade seladora dos cimentos Fillcanal, Ketac-Endo e AH Plus. Utilizaram 99 incisivos centrais superiores humanos extraídos, que tiveram seus canais instrumentados a $2 \mathrm{~mm}$ além do forame apical, com uma lima Nitiflex $n^{\circ} 55$ e, em seguida, obturados pela técnica da condensação lateral com cada um dos cimentos, anteriormente citados. Os dentes tiveram suas superfícies externas impermeabilizadas com esmalte para unhas, com exceção do forame apical e uma área de aproximadamente $1 \mathrm{~mm}$ de diâmetro ao seu redor. Em seguida, foram imersos em solução de azul de metileno a $2 \%$ por $24 \mathrm{~h}$. Após análise dos resultados, os autores concluíram que não houve diferença estatística significante na infiltração apical entre os canais obturados pelo Fillcanal e Ketac-Endo, tendo o AH Plus uma infiltração significantemente menor que os outros dois cimentos. 
BRANDÃO: MORAES; BRAMANTE ${ }^{9}$, em 2001, avaliaram a capacidade seladora apical de dois cimentos endodônticos ionoméricos, Ketac Endo e Vidrion Endo, comparando-os ao Sealer 26. A metodologia utilizada foi a infiltração apical, com o uso do corante azul de metileno a $1 \%$, em obturações pela técnica do cone único em canais de dentes unirradiculados humanos. Os resultados mostraram não haver diferença estatística na infiltração apical entre os canais obturados pelos cimentos ionoméricos, porém, essa diferença ocorreu entre os mesmos e o Sealer 26, o qual apresentou menores médias de infiltração.

TIMPAWAT: AMORNCHAT: TRISUWAN ${ }^{67}$, em 2001, compararam a capacidade de selamento coronário oferecido pelos cimentos AH Plus, Apexite Ketac-Endo, na obturação de canais radiculares pela técnica da condensação lateral. Utilizaram 75 dentes unirradiculados que tiveram suas coroas cortadas na junção cemento-esmalte e canais radiculares instrumentados, sendo, então, divididos em 3 grupos experimentais, de 19 raízes, de acordo com os cimentos testados e mais 2 grupos de 9 raízes cada, os quais serviram de controle negativo e positivo. Terminada a obturação, a parte cervical da mesma foi colocada em contato com os microorganismos E. faecalis, e a infiltração bacteriana foi medida nos períodos de 30 e 60 dias. Os autores concluíram que no período de 30 dias, o cimento Apexit foi o que possibilitou maior infiltração e o Ketac-Endo menor, ficando o AH Plus numa posição intermediária. No período de 60 dias, o AH Plus foi o que apresentou menor média de infiltração e o Apexit a maior, com diferença estatística significante, ficando o Ketac-Endo numa posição intermediária.

MAZOTTI: BONETTI FILHO ${ }^{44}$, em 2001, avaliaram a capacidade de preenchimento do sistema de canais radiculares, utilizando-se das técnicas de condensação lateral ativa, híbrida modificada, ultra-som Enac, thermafil, Microseal e System B. Foram utilizados 174 dentes humanos extraídos, 
unirradiculados, incluídos em bloco de resina, seccionados longitudinalmente, unidos em aparato de madeira com parafusos e divididos em seis grupos com 29 dentes cada. Em seguida, foi realizada a instrumentação dos canais, e ao fim desta, foram feitas depressões em cada terço do canal radicular, em uma das metades do dente. A seguir, os dentes tiveram seus canais obturados com as técnicas anteriormente citadas. Os autores concluíram que as técnicas Microseal $e$ Thermafil foram as que apresentaram melhores resultados quanto a capacidade de preenchimento, número de falhas e homogeneidade em relação as técnicas da condensação lateral ativa, híbrida modificada, ultra-som Enac e System B.

MELLO; ANTONIAZZI; ROBAZZA ${ }^{46}$, em 2001, avaliaram a influência da aplicação do laser Er:YAG, após o preparo químico-cirúrgico no selamento marginal apical quando da utilização de diferentes cimentos obturadores. Os espécimes utilizados no experimento foram separados em quatro grupos de acordo com o cimento a ser utilizado: Sealapex, N-Rickert, AH Plus e Ketac-Endo. Metade dos dentes de cada grupo recebeu tratamento nas paredes do canal radicular com o laser Er:YAG para remover o magma dentinário enquanto a outra metade não recebeu.. Após obturação, o selamento marginal foi determinado através da penetração da solução de azul de metileno a 0,5\% na interface material obturador/parede dentinária. Pela análise dos resultados, os autores concluíram que não houve diferença estatística de penetração do agente indicador entre os dentes submetidos à aplicação do laser e os dentes que não receberam esse tratamento. Entretanto, para os cimentos testados, as diferenças ocorreram entre o grupo formado pelo AH Plus e N-Rickert, com menor índice de infiltração em relação ao grupo formado pelo Ketac-Endo e Sealapex.

POMMEL: CAMPS ${ }^{58}$, em 2001, compararam "in vitro" a infiltração apical proporcionada pelas técnicas de obturação do System B, técnica do cone 
único, condensação lateral, condensação vertical e Thermafil. Após instrumentação dos canais radiculares pelo sistema Profile, 5 grupos de 10 dentes unirradiculados tiveram os canais obturados de acordo com as técnicas anteriormente citadas. A infiltração apical foi medida por meio de um sistema de filtração de fluidos, e os autores concluíram que num período de 24 horas, a técnica do cone único obteve maior infiltração, ao passo que em 1 mês, as técnicas do System $B$, Thermafil e condensação vertical tiveram menor infiltração que as outras duas, ficando a técnica do cone único com maior infiltração.

JACOBSON et al. ${ }^{34}$, em 2002, compararam a infiltração coronária bacteriana, em canais obturados pela técnica do System B associada ao Obtura II e pela técnica da condensação lateral. Foram utilizados 60 dentes unirradiculados humanos, extraídos, que tiveram suas coroas cortadas e canais radiculares instrumentados pelo sistema Great Taper. Após instrumentação, os canais foram irrigados com solução de EDTA a 15\% e os espécimes divididos em 2 grupos de 20, de acordo com a técnica de obturação empregada. Vinte dentes serviram para os grupos controles positivo e negativo. Os autores concluíram que a infiltração microbiana coronária ocorreu mais rapidamente nos canais obturados pela técnica da condensação lateral do que pela técnica do System B, com diferença estatística significante. Entretanto, não se observou diferença significante entre os grupos, em relação ao número de canais que demonstraram infiltração bacteriana ao final do estudo. 
3 PROPOSIÇÃO 


\section{PROPOSIÇÃO}

Este trabalho teve como proposta:

1 - Avaliar in vitro a influência do tratamento das paredes de canais radiculares, previamente à obturação, com a aplicação do laser de Nd:YAG ou solução de EDTA trissódico, na capacidade seladora de obturações realizadas com dois tipos de cimento e a possível interação entre os tratamentos e os cimentos utilizados.

2 - Verificar, sob microscopia eletrônica de varredura, as características das paredes dos canais radiculares nos terços médio e apical, após tratamento pela solução de EDTA trissódico e pelo laser Nd:YAG. 
4 MATERIAL E MÉTODOS 


\section{MATERIAL E MÉTODOS}

Seleção dos dentes

Foram selecionados sessenta e oito pré-molares inferiores humanos extraídos, unirradiculados, com canal único, provenientes do arquivo de dentes, da disciplina de Endodontia, do Departamento de Dentística, Endodontia e Materiais Dentários da FOB - USP. Estes dentes estavam armazenados em solução de formol a 10\%, sendo então lavados sob água corrente e mantidos em solução fisiológica até o momento de sua utilização.

Preparo dos dentes

Os dentes tiveram suas coroas removidas na junção amelocementária com o uso de um disco de carburundum e em seguida foi determinado - comprimento do canal, nivelando-se a ponta ativa de uma lima tipo $K n^{\circ} 15$ (Dentsply-Maillefer - Ballaigues, Suíça) com o forame apical. Procedeu-se, então, a padronização do forame apical instrumentando-se o canal, nesse limite, até a lima tipo $K n^{\circ} 25$ (Dentsply-Maillefer - Ballaigues, Suíça). Subtraindo-se um milímetro da medida estabelecida, determinou-se o comprimento de trabalho, e os canais foram, então, instrumentados, pela técnica coroa-ápice. Inicialmente, foi introduzida uma lima Profile 25.06, acionada pelo motor Endomate (NSK, Japão), no terço cervical e médio do canal, abrindo espaço para utilização das brocas de Gates-Glidden 2, 3 e 4, com recuo de $2 \mathrm{~mm}$ entre cada broca utilizada. Posteriormente, progrediu-se ao terço apical a partir da lima Profile 25.06, com limas de menores calibres, até atingir o comprimento de trabalho. Neste comprimento, dilatou-se o terço apical até o instrumento Profile 35.06, determinando o diâmetro cirúrgico de instrumentação. 
Durante a fase de instrumentação, os canais foram irrigados com uma solução de hipoclorito de sódio a 1\% (Myaco do Brasil ind e com. Ltda. SP, Brasil). Ao término desta, receberam uma irrigação final com soro fisiológico $e$, em seguida, foram secos por aspiração e cones de papel. Em seguida, as superfícies externas radiculares de 60 dentes foram impermeabilizadas com uma camada de Araldite 24 horas (Adesivo epóxi - Ciba especialidades químicas Ltda - SP) e uma camada de esmalte para unhas, respeitando-se as proximidades do forame apical, numa extensão média de $1 \mathrm{~mm}$ ao redor do mesmo.

Para evitar possível obliteração do forame pelos agentes impermeabilizadores, no momento da impermeabilização foi colocado um cone de guta-percha no interior do canal, de forma que sua ponta extravasasse pelo forame apical.

Tratamento da parede do canal radicular e obturação do sistema de canais

Após a secagem do agente impermeabilizador, sessenta raízes foram divididas em 4 grupos de 15, de acordo com o tipo de tratamento ao qual foi submetida a parede do canal radicular e o tipo de cimento utilizado para obturação do sistema de canais radiculares.

Grupo I - aplicação do laser Nd:YAG (SMARTY-A10, Deka, Itália - Figura 1) e obturação com cimento AH Plus (Dentsply De Trey, Konstanz, Alemanha).

Grupo II - aplicação do laser Nd:YAG e obturação com cimento Endofill (Dentsply, Petróplis).

Grupo III - aplicação de EDTA trissódico (Biodinâmica, PR - Figura 2) por 5 minutos e obturação com cimento AH Plus (Figura 3). 
Grupo IV - aplicação de EDTA trissódico por 5 minutos e obturação com cimento Endofill (Figura 4).

Os parâmetros utilizados para a aplicação do laser $N d: Y A G$, pulsátil, de 1,06 nm de comprimento de onda, foram de $15 \mathrm{~Hz}$ de frequência, $1.5 \mathrm{~W}$ de potência e $100 \mathrm{~mJ}$ de energia. Para a utilização no interior dos canais radiculares, foi utilizada uma fibra óptica de 200 micrometros (Figura 5) de diâmetro. A ponta da fibra era medida $e$, em seguida, introduzida até o comprimento de trabalho, com o canal seco, e então, o laser era acionado, nos parâmetros anteriormente citados. A seguir, a fibra era removida do interior do canal, em movimento helicoidal, procurando tocar todas as paredes do canal, até atingir o tempo de aplicação. Para cada canal radicular foram feitas duas aplicações de 7,5 segundos, totalizando 15 segundos por canal.

A solução de EDTA trissódico foi aplicada no interior dos canais com auxílio de uma seringa de $5 \mathrm{ml}$ com agulha hipodérmica, e logo após era introduzida uma lima tipo $K$ número 20 até o comprimento de trabalho, realizando-se um bombeamento dessa solução por 1 minuto. Terminado o período de aplicação de 5 minutos, os canais foram irrigados com soro fisiológico e, em seguida, secos para serem obturados.

A obturação dos canais radiculares, para todos os grupos, foi realizada pela técnica do System B (Analytic Technology, Redmont, WA, USA) e Obtura II (Obtura Corp., Fenton, MO, USA), da seguinte forma:

- Calibragem da ponta do cone de guta-percha fine-medium (Ultimate Dental, Korea) em 350 micrometros de diâmetro, utilizando régua calibradora.

- Prova do cone. 
- Colocação do cimento no interior do canal radicular até o limite de trabalho com auxílio de uma lima tipo K número 25 (Dentsply-Maillefer - Ballaigues, Suíça).

- Introdução e assentamento do cone envolto por cimento até o limite de trabalho.

- Introdução da ponta FM (fine-medium) do System B a $5 \mathrm{~mm}$ do limite de trabalho, obturando o terço apical.

- Obturação do terço cervical e médio por guta-percha termoplastificada pelo sistema Obtura II.

Terminada a obturação, a parte mais coronária da raiz foi coberta por um capuz de cera rosa derretida, completando a impermeabilização.

Para controle da impermeabilização e da própria capacidade de infiltração do corante, duas raízes não tiveram os canais obturados, sendo que uma delas foi totalmente impermeabilizada (controle negativo), inclusive em sua porção apical, enquanto que na outra (controle positivo) apenas o forame apical e $1 \mathrm{~mm}$ ao seu redor ficou livre da impermeabilização.

Para todos os procedimentos de instrumentação e obturação as raízes foram fixadas em um mecanismo de apreensão (mini torno - Western India). Para isto, as mesmas eram envoltas totalmente por um dispositivo circular de borracha sendo, então, fixadas.

As raízes foram imersas em solução de azul de metileno a $2 \%$ durante 48 horas, em estufa a $37^{\circ} \mathrm{C} \pm 2$ e ao final desse período realizou-se a lavagem em água corrente por 12 horas. Em seguida, foi removida a 
impermeabilização, realizando-se, então, o desgaste da raiz numa das faces proximais até expor a obturação. Para leitura da magnitude das infiltrações (Figuras 6 a 9), foi utilizado um microscópio óptico (Bausch \& Lomb, EUA) com ocular micrométrica (Carl Zeiss, Alemanha) pela técnica da planimetria. A infiltração marginal apical foi medida, tomando-se como ponto de referência inicial o batente apical até o ponto máximo da infiltração linear do corante, na interface obturação-dentina nas paredes vestibular e lingual. Considerou-se a face de maior infiltração. As medições foram feitas por 2 examinadores e os dados aferidos foram levados para análise estatística, para aplicação do teste paramétrico análise de variância a dois critérios.

\section{Preparo dos espécimes para microscopia eletrônica de varredura}

Os seis espécimes restantes tiveram os canais instrumentados, seguindo-se os mesmos padrões descritos anteriormente e, em seguida, metade teve as paredes dos canais tratadas pelo laser Nd:YAG e a outra pela solução de EDTA, de acordo com o protocolo anterior. Na sequência, foram feitos dois sulcos longitudinais nas raízes, um na vestibular e outro na lingual, partindo-as com auxílio de uma espátula tipo lecron. As raízes foram fixadas com esmalte para unhas em uma base de metal ("stub"), com $1 \mathrm{~cm}$ de altura e 0,9 de diâmetro, de modo que a parede do canal radicular ficasse voltada para o observador.

O conjunto foi levado ao aparelho metalizador HUMMER VII, o qual recobriu os espécimes com uma camada de ouro de $20 \mathrm{~nm}$ de espessura. 
Fotomicrografias em microscopia eletrônica de varredura $e$ análise das características das paredes dos canais radiculares

Os espécimes preparados foram levados ao microscópio eletrônico de varredura, modelo JEOL JSM-T220 A, operando com $15 \mathrm{kV}$, para realização de fotomicrografias que foram obtidas com uma máquina fotográfica MAMIYA $50 A$ - MRH, acoplada ao microscópio eletrônico, utilizando filme Neopan 100 ACROS preto e branco, obtendo-se fotomicrografias com aumento de 1000x.

Assim, pode-se observar as características das paredes dos canais radiculares após tratamento pela solução de EDTA trissódico e pelo laser Nd:YAG, nos terços médio e apical (Figuras 11 a 13). 


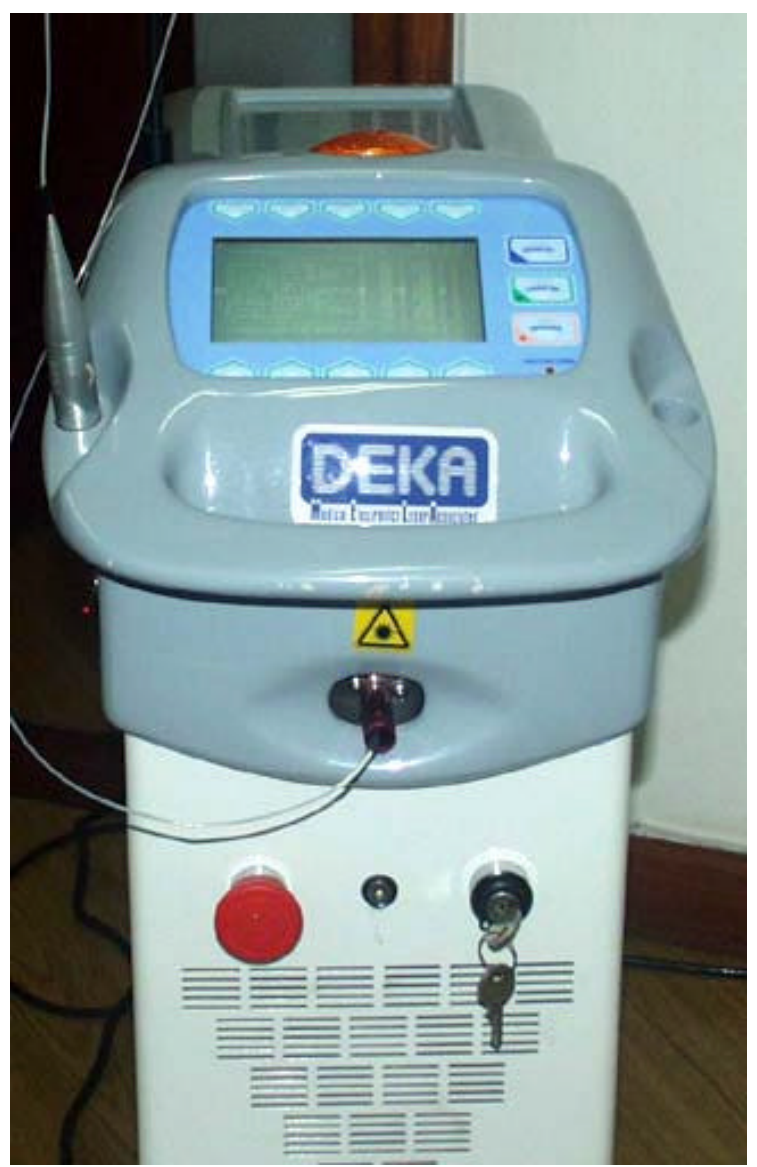

Figura 1 - Aparelho de laser Nd:YAG (SMARTY-10)

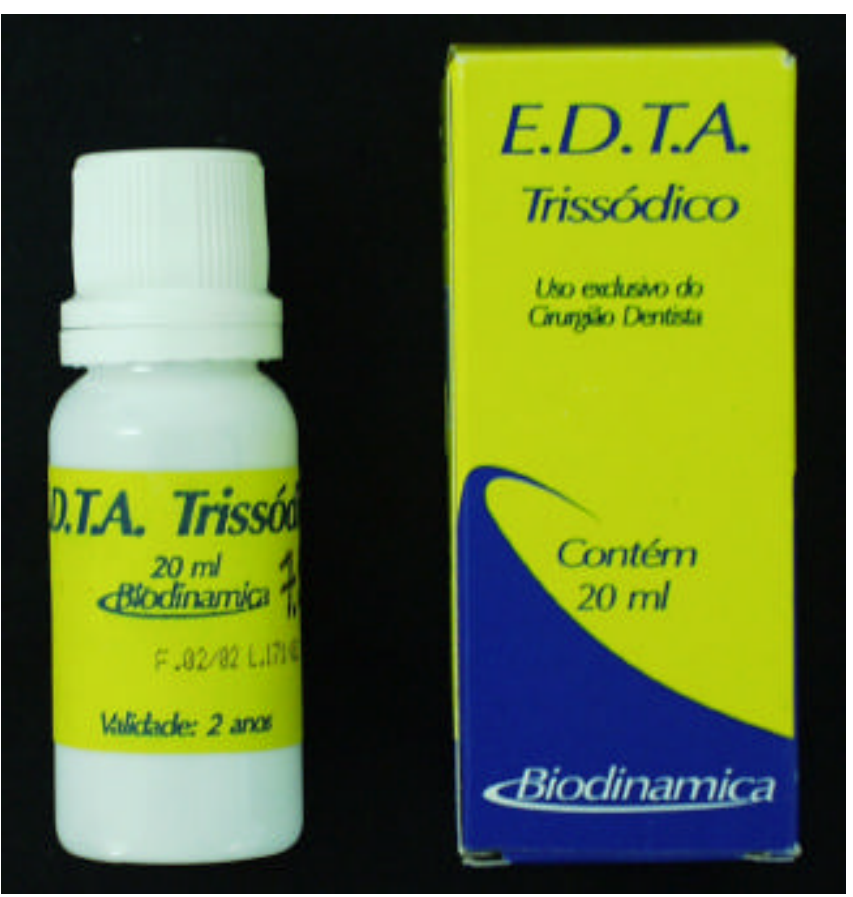

Figura 2 - Solução de EDTA trissódico 


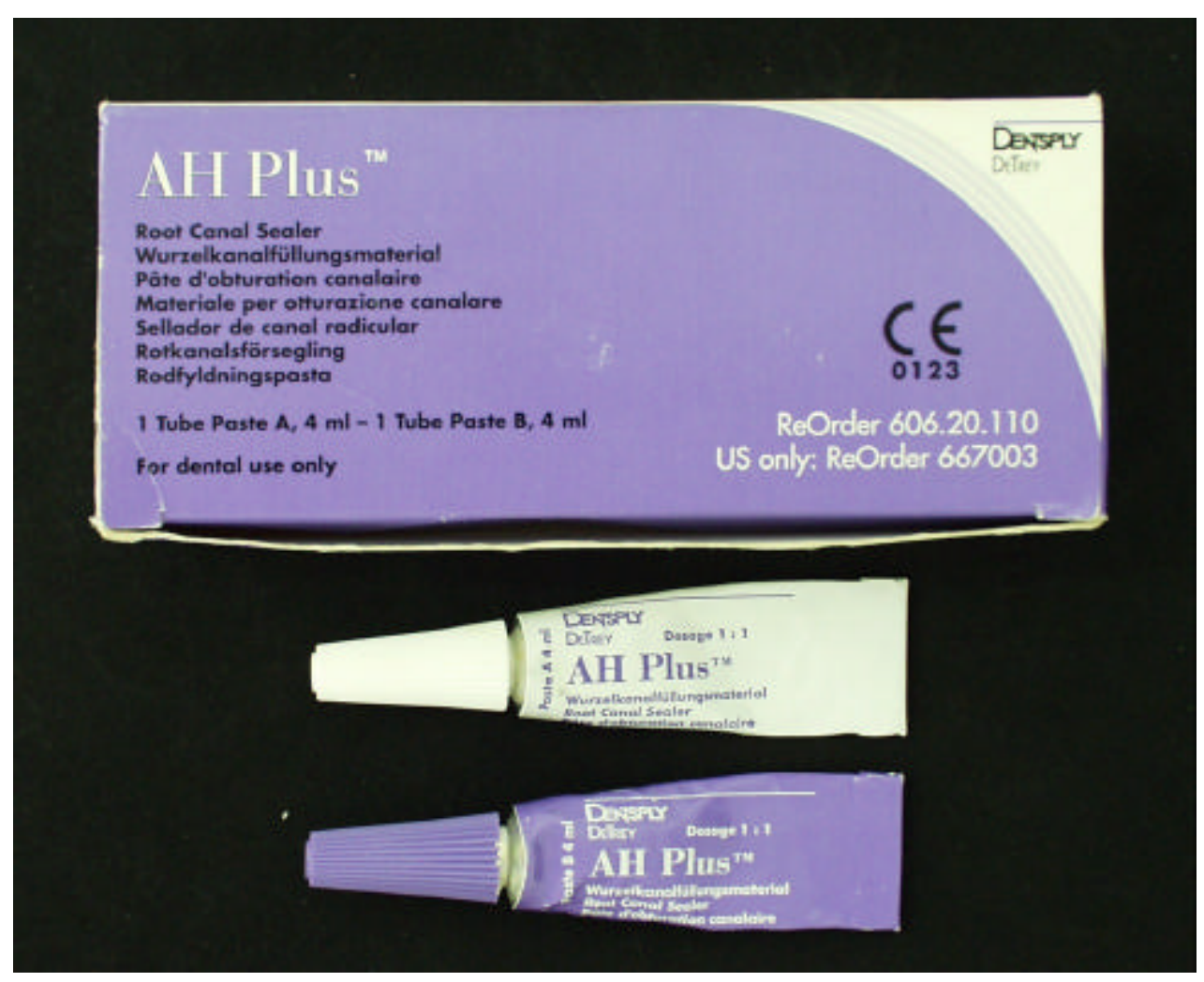

Figura 3 - Cimento obturador AH Plus

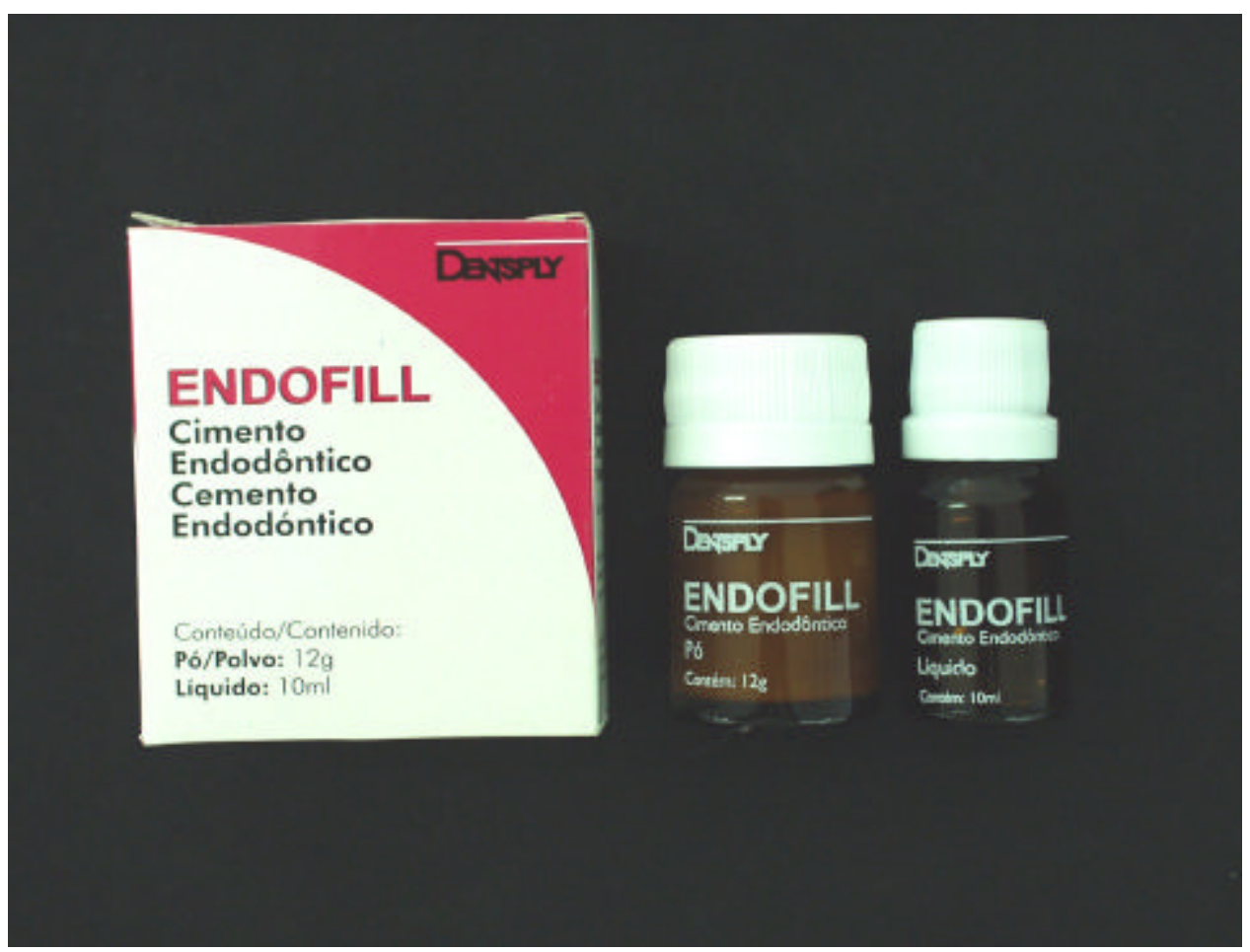

Figura 4 - Cimento obturador Endofill 


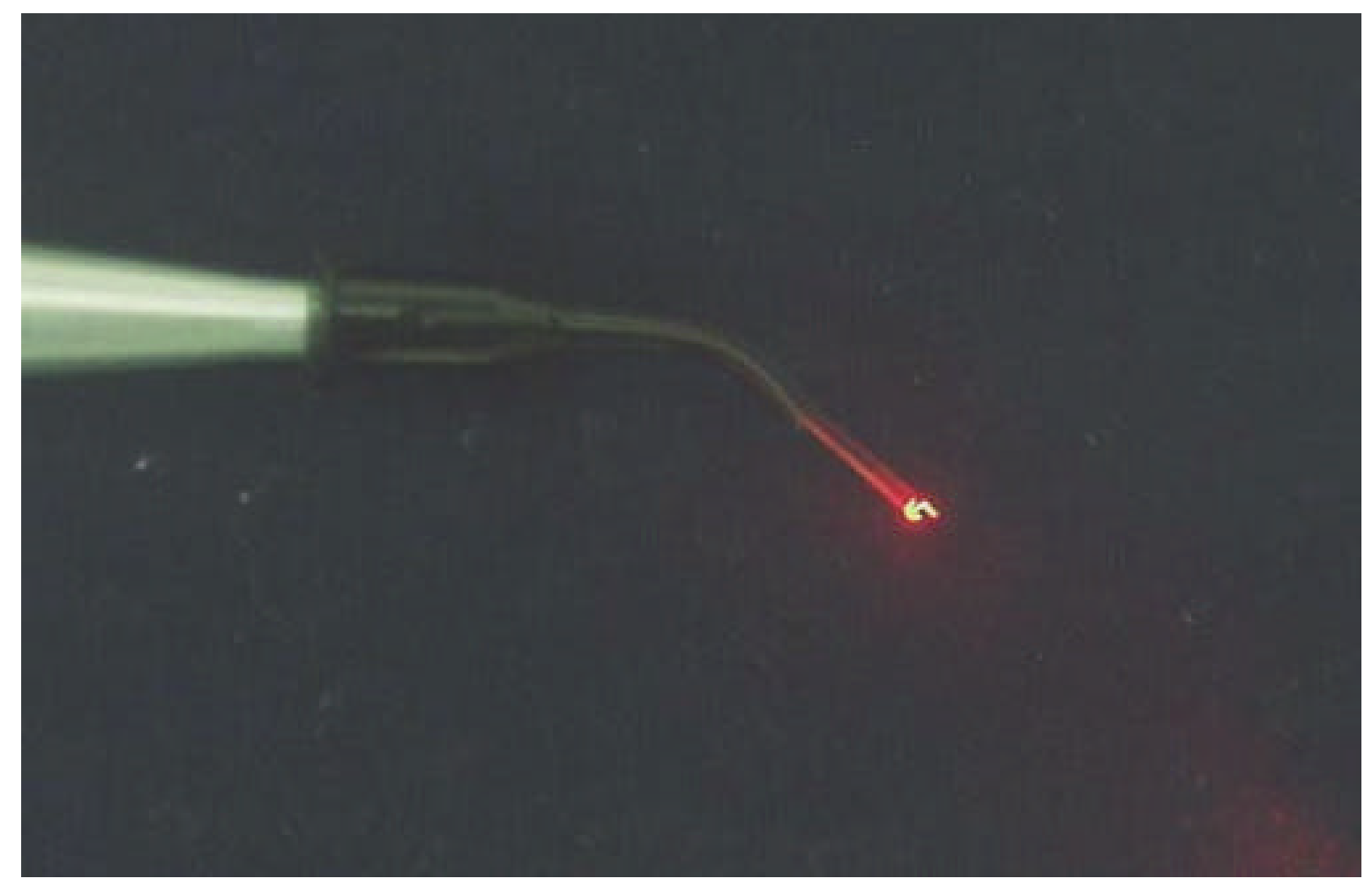

Figura 5 - Fibra óptica de 200 micrometros de diâmetro para aplicação do raio laser 


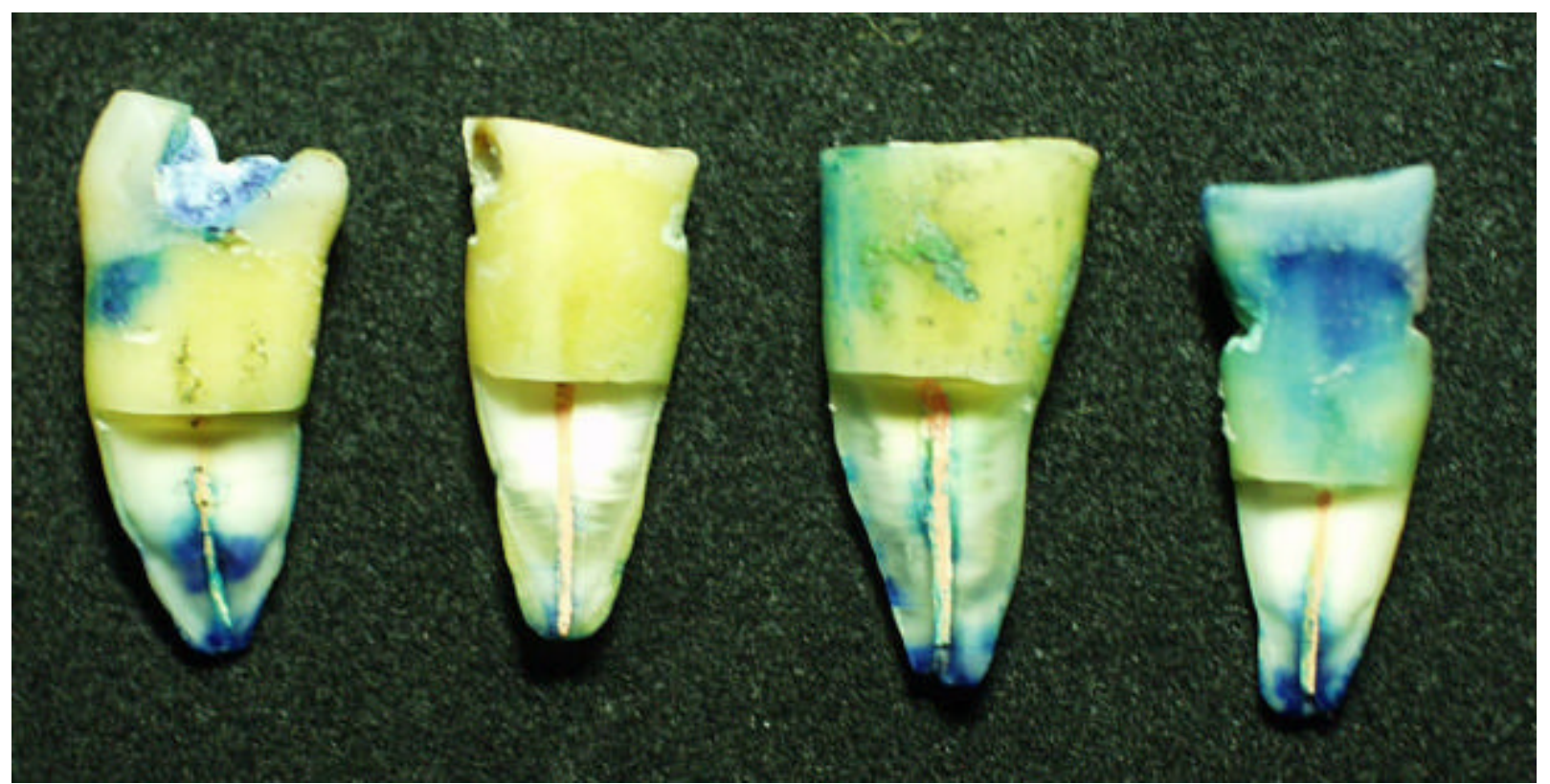

Figura 6 - Infiltração apical da solução de azul de metileno - irrigação final com EDTA e obturação com o cimento Endofill

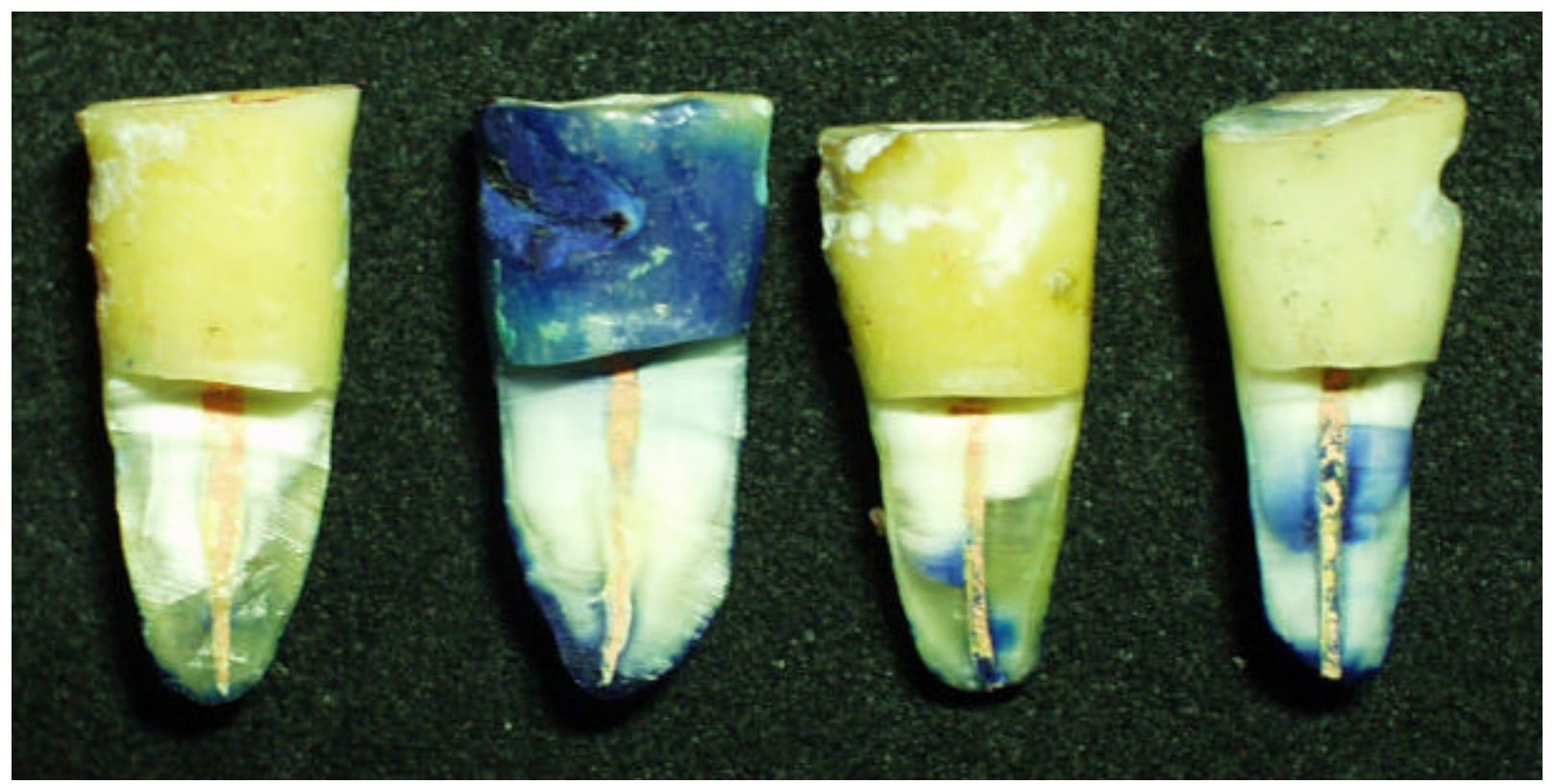

Figura 7 - Infiltração apical da solução de azul de metileno - irrigação final com EDTA e obturação com o cimento AH Plus 


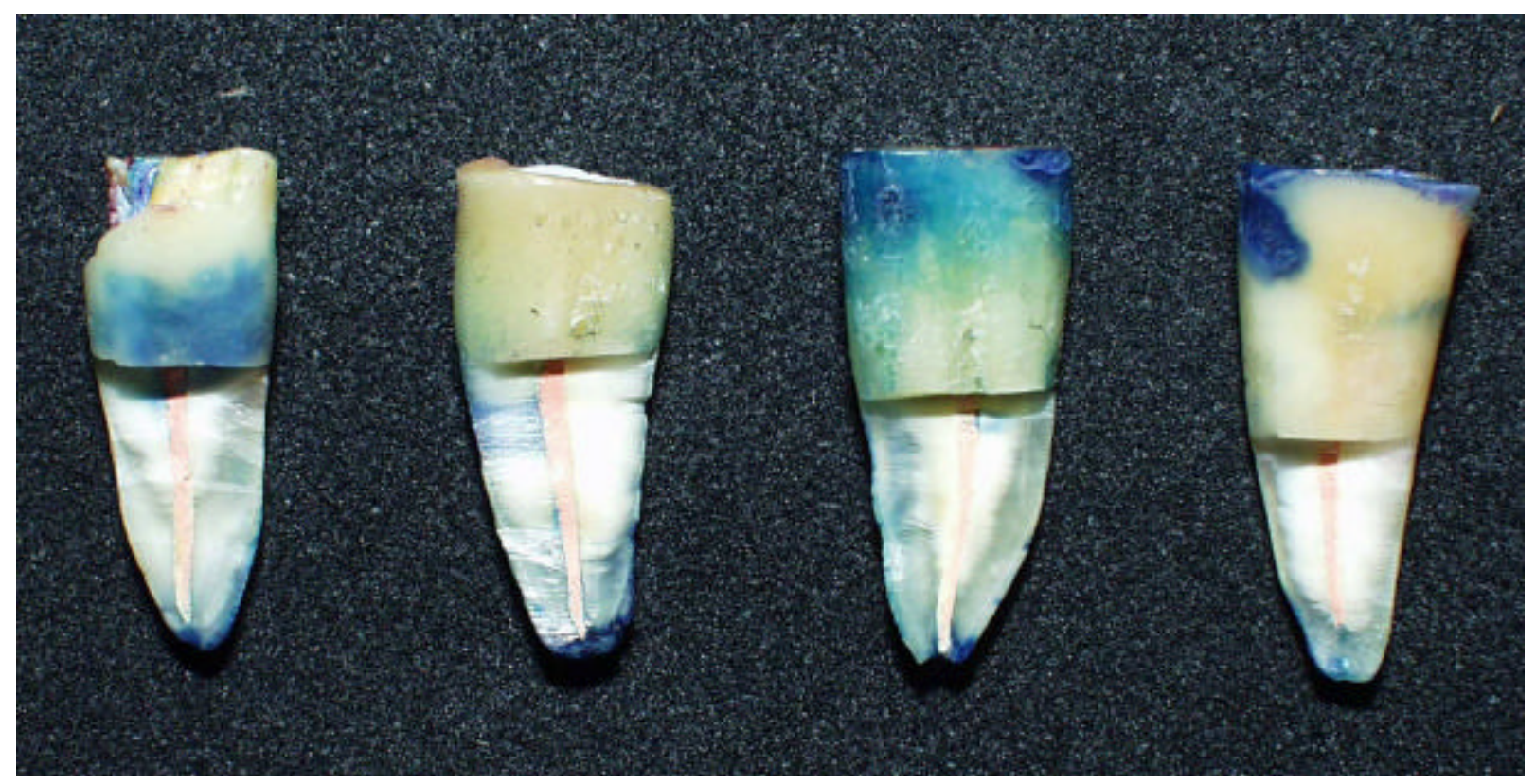

Figura 8 - Infiltração apical da solução de azul de metileno - irradiação com laser e obturação com o cimento Endofill

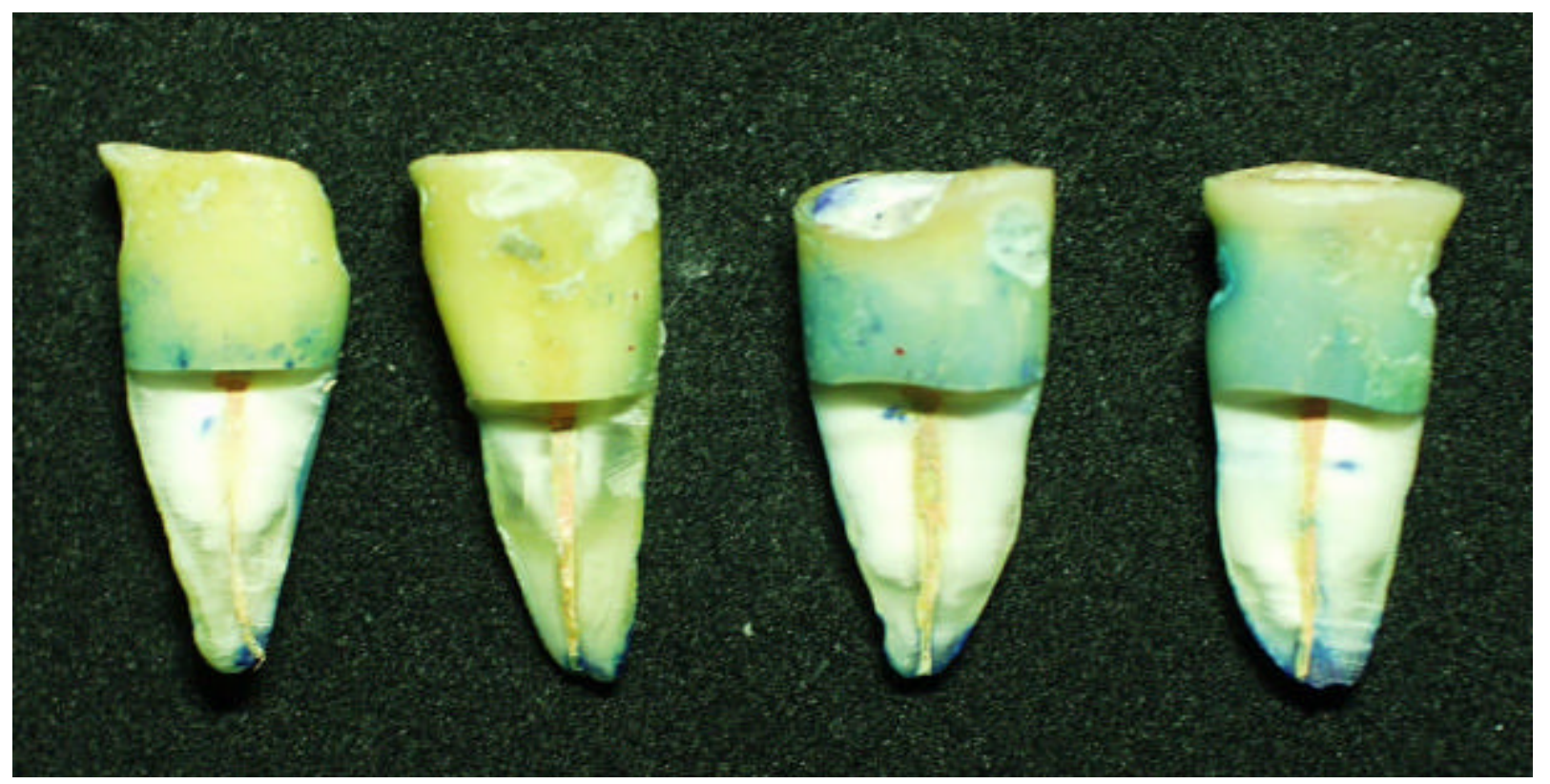

Figura 9 - Infiltração apical da solução de azul de metileno - irradiação com laser e obturação com o cimento AH Plus 


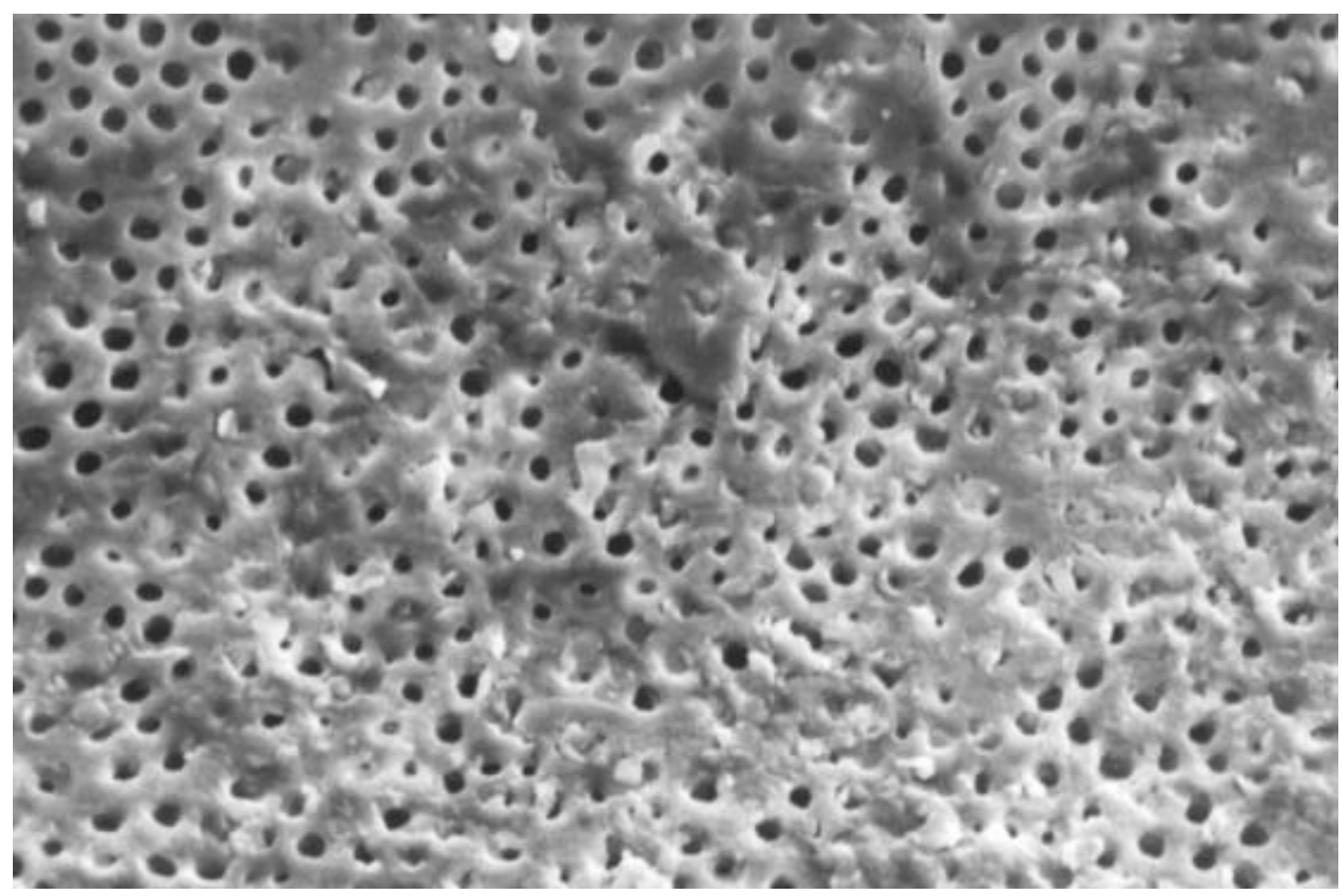

Figura 10 - Fotomicrografia da parede do terço médio do canal radicular após aplicação do EDTA (aumento de 1000x)

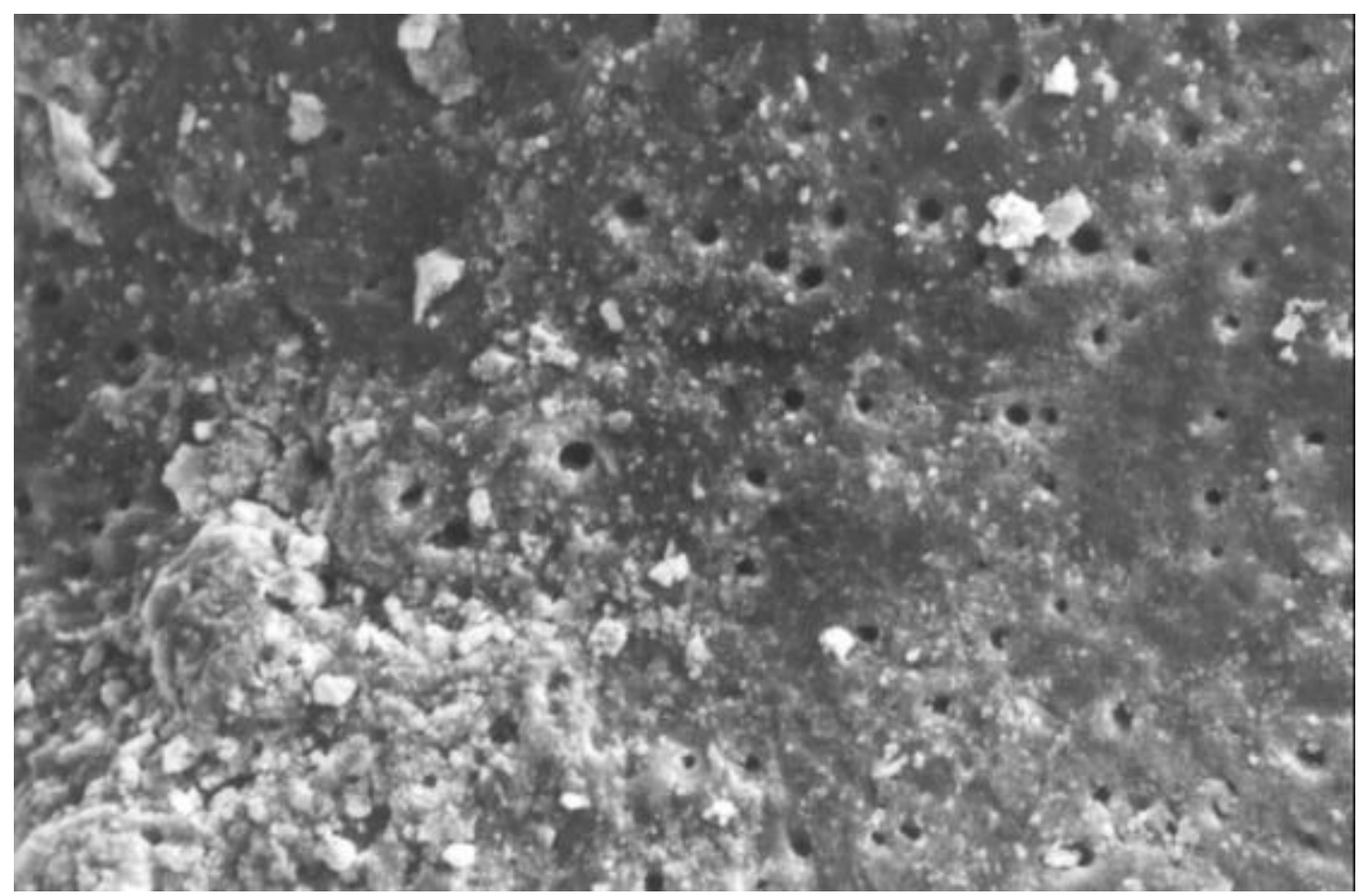

Figura 11 - Fotomicrografia da parede do terço apical do canal radicular após aplicação do EDTA (aumento de 1000x) 


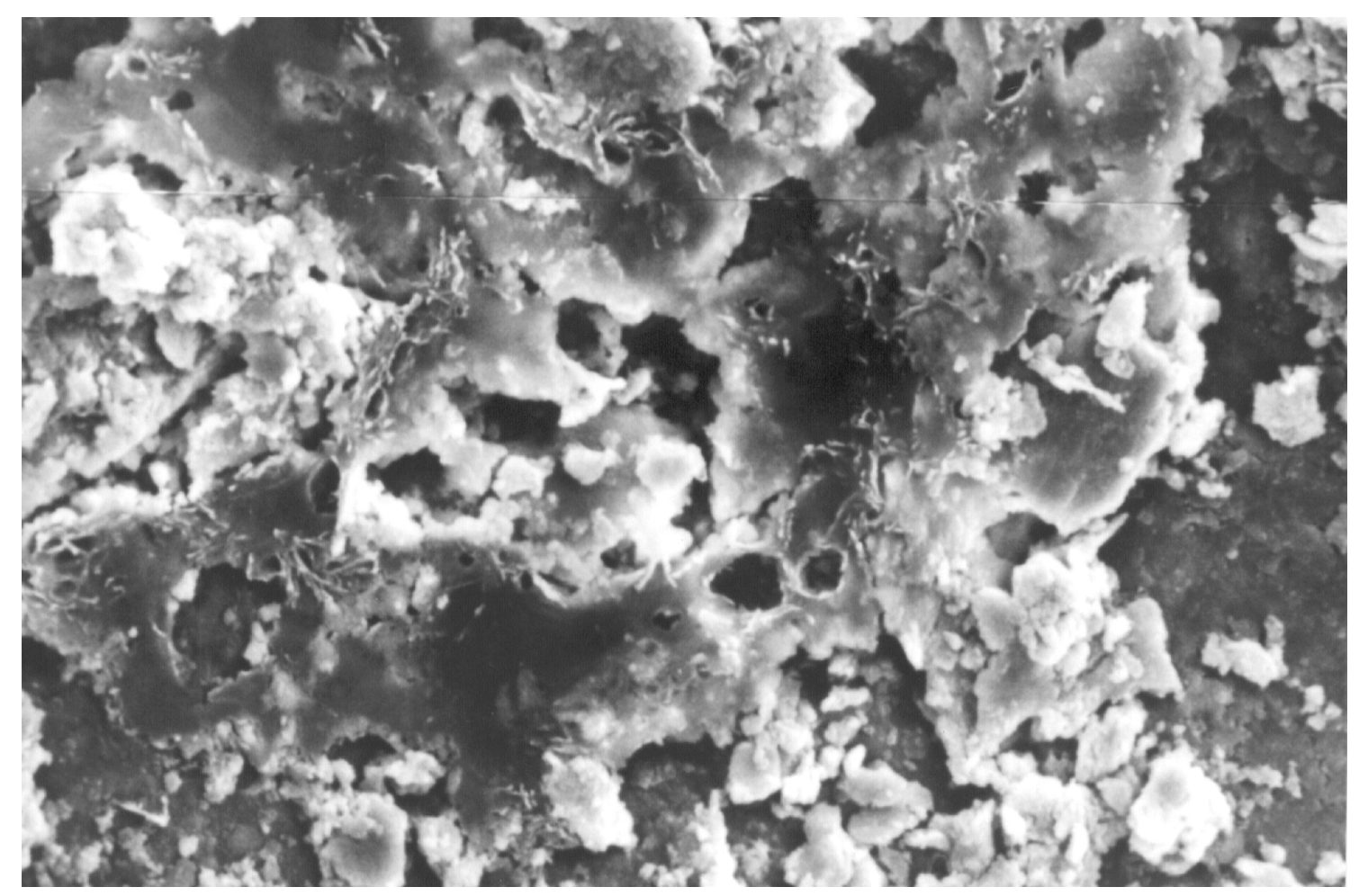

$\underline{A}$

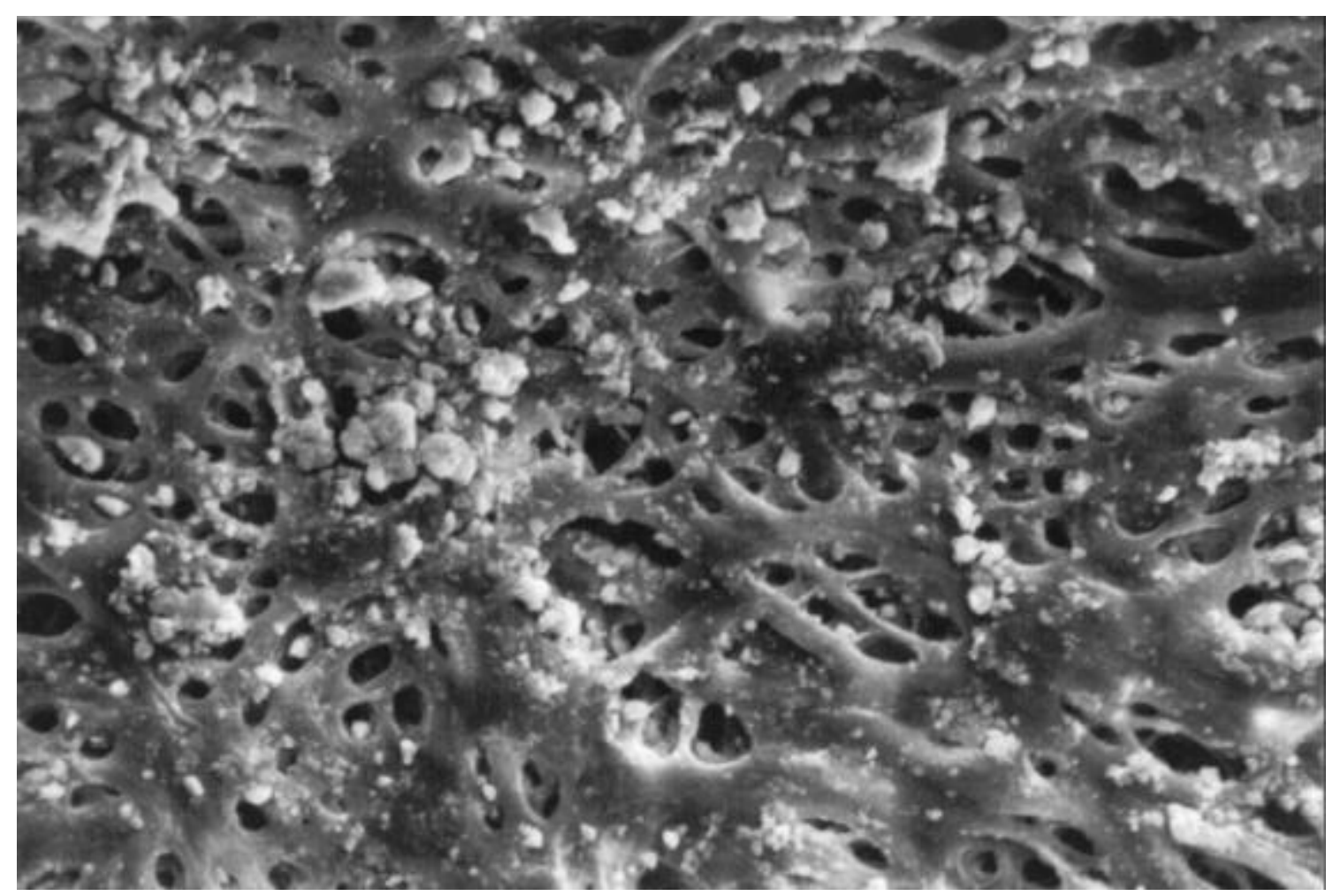

$\underline{B}$

Figura 12 ( $A$ e B) - Fotomicrografias da parede do terço apical do canal radicular irradiada pelo laser (aumento de 1000x) 


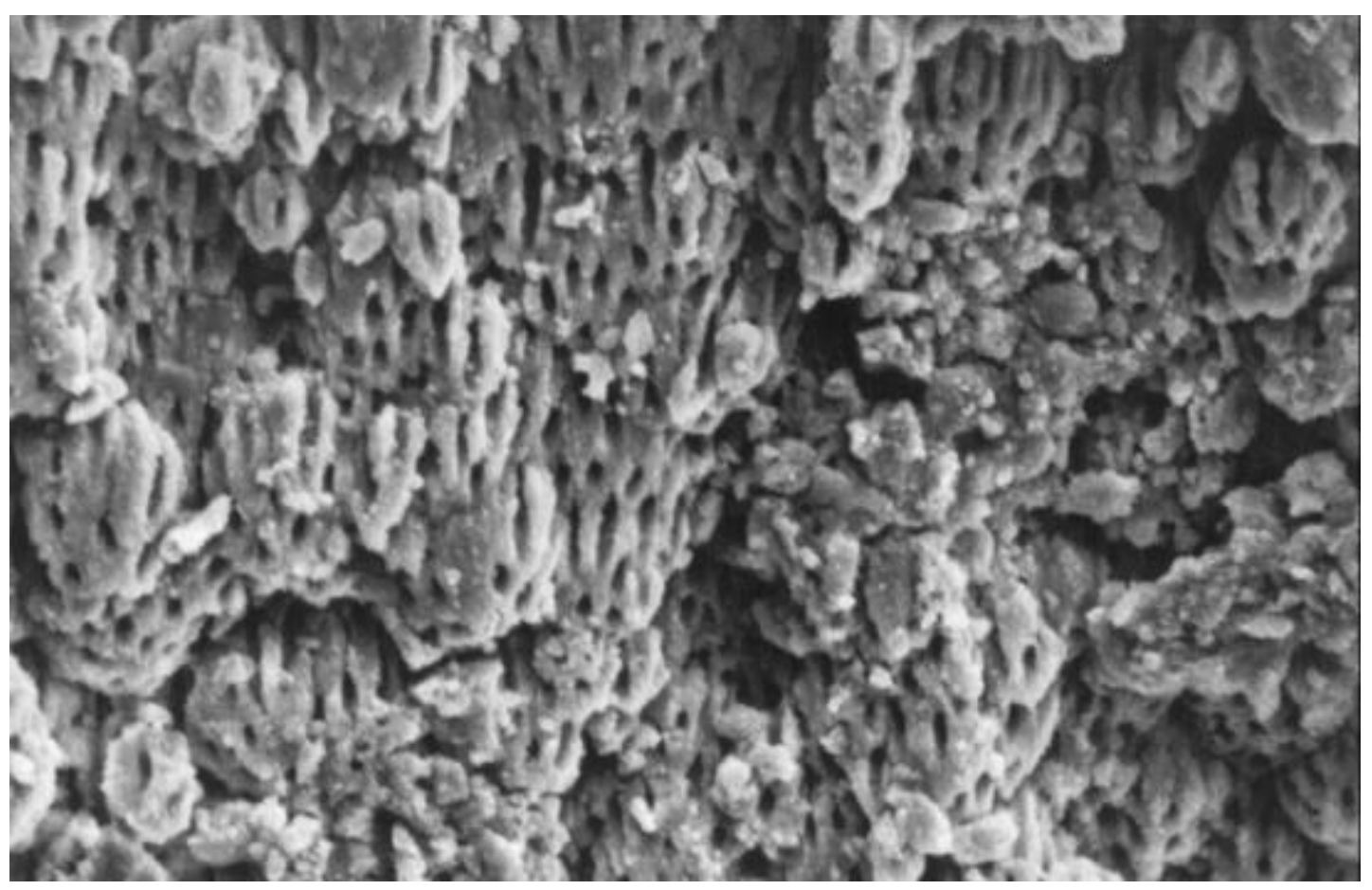

$\underline{A}$

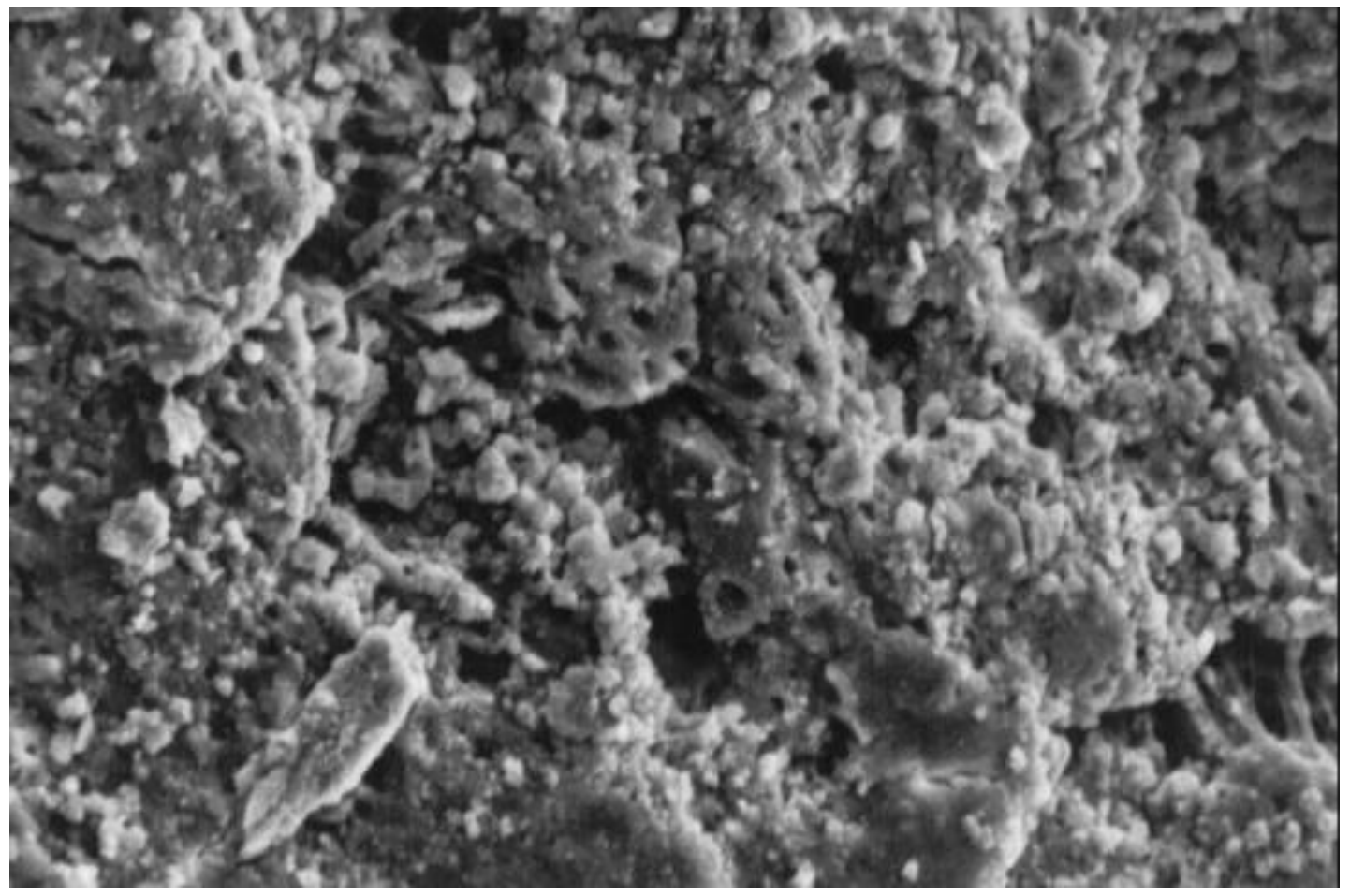

$\underline{B}$

Figura 13 ( $A$ e B ) - Fotomicrografias da parede do terço médio do canal radicular irradiada pelo laser (aumento de 1000x) 
5 RESULTADOS 


\section{RESULTADOS}

As médias de infiltração marginal apical evidenciada pelo corante azul de metileno a $2 \%$ ao longo da interface dentina/obturação, medidas em milímetros, assim como os desvios padrão obtidos em função dos tratamentos da parede do canal radicular e dos cimentos utilizados na obturação estão representados na tabela 1 e na figura 14.

\begin{tabular}{c|c|c|c|c}
\hline GRUPO & $\begin{array}{c}\text { TRATAMENTO DA } \\
\text { PAREDE }\end{array}$ & CIMENTO & MÉDIA & $\begin{array}{c}\text { DESV. } \\
\text { PAD. }\end{array}$ \\
\hline I & laser Nd:Yag & AH Plus & 0,99 & 0,68 \\
\hline II & laser Nd:Yag & Endofill & 1,93 & 1,00 \\
\hline III & EDTA & AH Plus & 2,54 & 0,84 \\
\hline IV & EDTA & Endofill & 4,20 & 1,52 \\
\hline
\end{tabular}

Tabela 1 - Médias de infiltração marginal apical, em milímetros e, desvios padrão, obtidos em função dos tratamentos da parede do canal radicular e dos cimentos utilizados na obturação. 


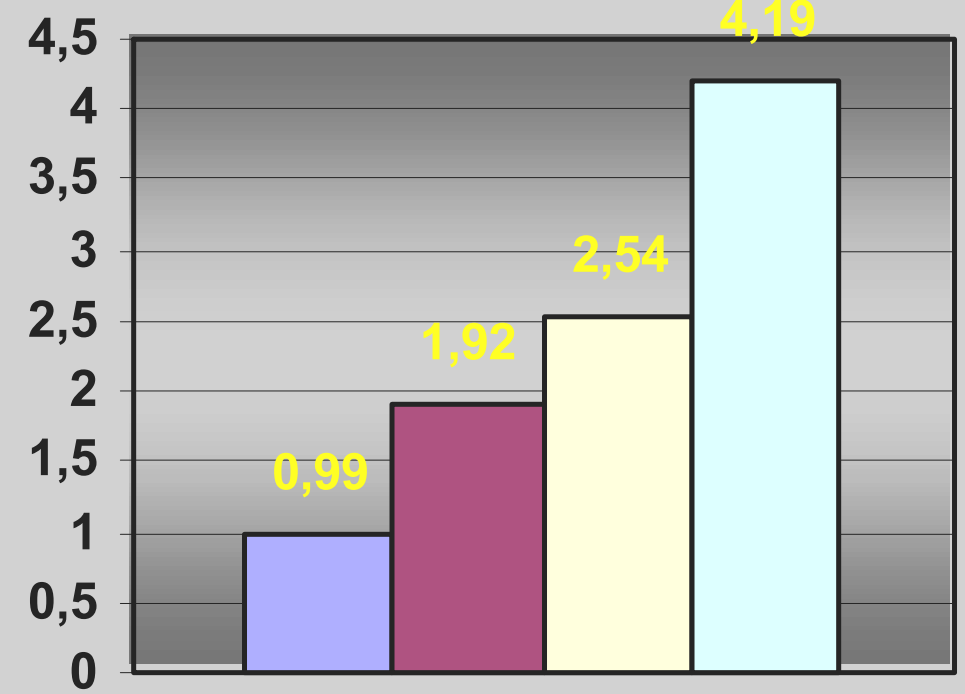

$\square$ laser + AH Plus

$\square$ laser + Endofill

$\square$ EDTA + AH Plus

$\square$ EDTA + Endofill

Figura 14 - Representação gráfica das médias de infiltração apical, em milímetros, propiciada pelos diferentes grupos. 
O teste estatístico paramétrico que melhor se adaptou ao modelo experimental foi a análise de variância a dois critérios, representado na tabela 2 a seguir.

\begin{tabular}{c|c|c|c|c|c|c}
\hline EFEITO & G.L. & Q.M. & G.L. & Q.M. & $F$ & $P$ \\
& EFEITO & EFEITO & ERRO & ERRO & & \\
\hline TRATAMENTO & $1^{\star}$ & $54,645^{\star}$ & $56^{\star}$ & $1,130^{\star}$ & $48,354^{\star}$ & $0^{\star}$ \\
CIMENTOS & $1^{\star}$ & $25,272^{\star}$ & $56^{\star}$ & $1,130^{\star}$ & $22,362^{\star}$ & $0^{\star}$ \\
INTERAÇÃO & 1 & 1,944 & 56 & 1,130 & 1,720 & 0,195 \\
\hline
\end{tabular}

* - diferença estatisticamente significante $(p<0,05)$

Tabela 2 - Análise de variância a dois critérios.

A análise de variância a dois critérios acusou diferença estatística significante $(p<0,05)$ tanto entre os tratamentos aplicados às paredes do canal radicular previamente à obturação quanto entre os cimentos utilizados, apontando valores favoráveis ao laser Nd:YAG e ao cimento AH Plus, respectivamente, sem, contudo apontar interação entre as variáveis testadas.

$\mathrm{Na}$ análise ao M.E.V., os espécimes que tiveram seus canais tratados pelo laser Nd:YAG, em alguns casos, apresentaram-se sem a "smear layer", exibindo superfícies com túbulos dentinários abertos (Figura 13A), e em outros, 
a smear layer se apresentou derretida e aderida à dentina, obliterando os túbulos dentinários, principalmente no terço apical (Figura 12A).

Os espécimes que tiveram seus canais tratados pela solução de EDTA, apresentaram as paredes do terço médio livre da "smear layer", com túbulos dentinários expostos (Figura 10). Já no terço apical, os mesmos espécimes apresentaram paredes parcialmente obliteradas pela "smear layer", com um menor número de túbulos dentinários expostos (Figura 11). 


\section{DISCUSSÃO}

A obturação dos canais radiculares caracteriza-se por uma das etapas mais importantes do tratamento endodôntico e, com ela, almeja-se o preenchimento de todo sistema de canais radiculares, de modo completo $e$ compacto, assegurando um selamento hermético, visto que o afluxo de fluidos através do forame apical ao sistema de canais radiculares poderia criar um meio com nutrientes, favorável ao crescimento bacteriano.

Ao final da instrumentação, as paredes dos canais radiculares encontram-se cobertas pela "smear layer", e a necessidade de sua remoção anteriormente à obturação, é controversa ${ }^{5}, 16,36,73$.

Existem diferentes formas para remoção da "smear layer", sendo a solução de EDTA a substância mais amplamente utilizada ${ }^{18,39,53,56}$. Por isso, optou-se neste trabalho, usar essa solução no preparo das paredes dos canais radiculares, previamente à obturação.

Os avanços tecnológicos têm sido bem aceitos no mundo científico após passarem por exaustivas investigações antes de serem indicados para o uso clínico. A utilização do laser na endodontia vem sendo pesquisada há alguns anos, mais precisamente, desde 1971, quando WEICHMAN; JOHNSON ${ }^{70}$, utilizando o laser $\mathrm{CO}_{2}$, tentaram selar externamente o forame apical de dentes humanos extraídos.

A utilização do laser no interior dos canais radiculares se tornou possível com o advento de fibras ópticas, de diâmetros variados, que possibilitam a aplicação do laser em toda a extensão do canal.

$O$ tratamento das paredes dos canais radiculares pelo laser $\mathrm{Nd}$ :YAG tem demonstrado uma redução na permeabilidade da dentina, a qual é derretida, selando os túbulos dentinários ${ }^{3}, 15,49$. 
A energia do laser Nd:YAG é absorvida pelas estruturas minerais, como os fosfatos e carbonatos da hidroxiapatita, desarranjando a grade cristalina (ablação termoquímica), promovendo o derretimento e a fusão do tecido dentinário.

Sendo assim, o outro tipo de preparo da parede do canal radicular anteriormente à obturação, utilizado nesta pesquisa, foi a aplicação do laser $\mathrm{Nd}$ Y $A G$, por meio de uma fibra óptica de 200 micrometros. Os parâmetros utilizados para a aplicação do laser Nd:YAG foram de $15 \mathrm{~Hz}$ de frequência, $1.5 \mathrm{~W}$ de potência e $100 \mathrm{~mJ}$ de energia, o que pode levar a um aumento de temperatura externa radicular de aproximadamente $3^{\circ} C^{45}$. LAN ${ }^{40}$, em 1999, avaliando a elevação de temperatura na superfície radicular no momento da aplicação do laser Nd:YAG, com diferentes parâmetros, concluiu que a $100 \mathrm{~mJ}$ de energia e 20 pps, $80 \mathrm{~mJ}$ e 25 pps e $60 \mathrm{~mJ}$ e 30pps, a temperatura externa radicular não excederia $10^{\circ} \mathrm{C}$ e, consequentemente, não provocaria injúrias ao osso alveolar.

A obturação do sistema de canais radiculares pode ser realizada por meio de diversas técnicas. Um dos materiais consagrados mundialmente pelo uso é a guta-percha, porém, normalmente ela não se adere às paredes do canal radicular e dependendo da técnica ela não preenche todo espaço anatômico do sistema de canais radiculares. Quando uma obturação é realizada sem o uso de cimento, a infiltração apical é alta ${ }^{68}$. Daí ser imprescindível a utilização de um cimento obturador. Os cimentos utilizados neste experimento foram o Endofill e - AH Plus. A escolha do cimento Endofill, à base de óxido de zinco e eugenol, deu-se devido à sua ampla utilização na Odontologia e por ser, também, uma das inúmeras marcas comerciais do cimento do tipo Grossman, mundialmente difundido. Quanto ao cimento AH Plus, sua escolha deveu-se ao fato de ser um cimento à base de resina epóxica, atual, disponivel no mercado e com boas propriedades no que diz respeito à sua capacidade seladora ${ }^{2}, 17,32$. 
A técnica de obturação do sistema de canais radiculares, mais amplamente utilizada, é a da condensação lateral. Entretanto, esta não foi escolhida para este trabalho, pois sua capacidade em replicar a superfície interna do canal radicular não é satisfatória, tendo como características uma obturação com fusão incompleta dos cones de guta-percha e presença de espaços mortos ${ }^{10}$.

A principal propriedade da guta-percha, quando utilizada na endodontia, é a capacidade de ser amolecida pelo calor e compactada pela compressão. Neste estudo, a obturação foi realizada utilizando-se da associação das técnicas, termoplastificadora system B e injetora Obtura II, pois estas possibilitariam a realização de uma obturação homogênea com melhor adaptação às paredes dos canais radiculares.

O marcador utilizado para identificar a infiltração marginal apical foi a solução de azul de metileno a $2 \%$, por ser este um dos mais utilizados ${ }^{1,2,9}$. 20, 62, 77, por apresentar bons resultados e ser facilmente observado por um microscópio óptico, com iluminação indireta, permitindo uma leitura rápida sem necessidade de equipamentos mais complexos. A solução de azul de metileno penetra nos espaços no interior dos canais radiculares em grande profundidade, mais que os radioisótopos ${ }^{42}$ e ainda tem como vantagens, solubilidade, boa capacidade de difusão e a incapacidade de reagir com tecido duro. Suas partículas são pequenas, menores que os microorganismos, mas compatíveis com as moléculas do ácido butílico, um produto bacteriano tóxico ${ }^{37}$.

No presente trabalho, a infiltração apical foi determinada linearmente por meio de desgaste da raiz e medição com auxílio de um microscópio óptico com ocular micrométrica, seguindo metodologia de outros autores $^{9}, 38,62$. 
As médias de infiltração dos grupos foram submetidas à análise estatística, sendo que, o teste estatístico paramétrico que melhor se adaptou ao modelo experimental foi a análise de variância a dois critérios. Esse teste acusou diferença estatística significante $(p<0,05)$ tanto entre os preparos aplicados às paredes do canal radicular previamente à obturação quanto aos cimentos utilizados, mas não mostrou diferenças entre as interações.

Pode-se verificar, por meio da análise de variância, a superioridade do cimento AH Plus em comparação ao Endofill no selamento apical, visto que o primeiro apresentou níveis menores de infiltração marginal apical. Este resultado está de acordo com o trabalho de ALMEIDA et al. ${ }^{2}$ que, comparando os cimento Endofill, Ketac-Endo e AH Plus, concluíram que este último obteve menor média de infiltração apical quando comparado com os outros dois, que tiveram resultados estatisticamente semelhantes.

Vários são os trabalhos que mostram a superioridade dos cimentos resinosos em se aderir à dentina 14, 22, 24, 29, e na capacidade de selamento apical 6, 9, 32 , principalmente, quando a "smear layer" é removida.

Entre os preparos realizados nas paredes dos canais radiculares, previamente à obturação, aquele com o laser $\mathrm{Nd}: Y A G$ foi o que provocou menor nível de infiltração marginal apical, com diferença estatística significante, em relação ao preparo com EDTA. Este resultado está de acordo com o trabalho de GOYA et al. ${ }^{27}$, que concluíram que a irradiação das paredes dos canais radiculares com laser $\mathrm{Nd}: Y A G$, principalmente com a associação à tinta nanquim, reduziu de forma significativa a infiltração apical de canais obturados. Os autores concluíram ainda, que a parede dos canais irradiada pelo laser, apresentava-se sem "smear layer", evidenciando superfícies com túbulos dentinários abertos e em outra parte a "smear layer" se apresentava derretida e aderida à dentina, obliterando os túbulos dentinários. Essas características da parede do canal radicular após a irradiação pelo laser $\mathrm{Nd}$ :YAG foi observada por 
vários autores $4,15,69,76$, como também neste estudo, como mostra a figura $12(A$ e $B)$.

Estudos para avaliação da permeabilidade da parede do canal radicular após o uso do laser $\mathrm{Nd}: Y A G$, demonstraram haver uma redução significativa da mesma ${ }^{49,63}$, principalmente no terço apical do canal ${ }^{3}$.

A eficiência do EDTA na remoção da "smear layer" da parede dos canais radiculares foi demonstrada por alguns autores ${ }^{12,25,59}$, assim como sua incapacidade na completa remoção da "smear layer" do terço apical dos canais radiculares $^{65,78}$

Dessa forma, os melhores resultados encontrados em relação à infiltração apical após o uso do laser $N d: Y A G$, podem estar relacionados ao fato de uma remoção mais efetiva da "smear layer" do terço apical do canal por esta técnica, o que permitiria um contato íntimo do material obturador com a parede do canal radicular. A permanência da "smear layer" no terço apical agiria como que uma interface entre o material obturador e a parede do canal radicular, servindo de caminho para a penetração do corante.

Além disso, aparece uma outra hipótese, principalmente em relação aos resultados observados quanto ao cimento AH Plus. Este apresenta em sua composição o óleo de silicone que, por suas características, é um material hidrófobo. ZMENER et al. ${ }^{77}$ observaram infiltração apical elevada em obturações realizadas com o $\mathrm{AH}$ Plus; relacionaram tal ocorrência à incompatibilidade umidade/óleo; umidade esta decorrente da dificuldade de se secar devidamente as paredes dos canais.

DUARTE* observou menor infiltração marginal em obturações realizadas com o AH Plus quando os canais foram secos utilizando-se o álcool isopropílico.

\footnotetext{
* Comunicação pessoal
} 
Observou-se, ao M.E.V. que nos casos onde o EDTA foi aplicado nas paredes dos canais, principalmente no terço apical, restou alguma quantidade de "smear layer" recobrindo as paredes. Como já salientado esta poderia servir de interface para a penetração do marcador, no caso o azul de metileno. Aliás, as fotomicrografias, obtidas neste trabalho ilustram bem tal fato (Figuras 10 a 13).

Há que considerar, inclusive, que as paredes analisadas ao M.E.V. foram as proximais, locais onde, durante a instrumentação mecanizada, a ação dos instrumentos se faz com mais eficiência, principalmente nos canais cujas formas anatômicas são ovaladas, o que não é incomum nos canais usados neste experimento. Tal circunstância permitiria que uma maior quantidade de "smear layer" fosse depositada, principalmente, na parede vestibular do canal, dificultando ainda mais sua completa remoção. Contudo, esta parede não foi analisada no M.E.V. A análise da infiltração foi realizada na interface obturação e paredes vestibular e lingual.

Assim, a própria presença da "smear layer" servindo de interface entre a obturação e a parede do canal, associada à maior dificuldade de se remover totalmente a umidade das paredes dos canais, pois, mesmo com a remoção da "smear layer" os túbulos dentinários abertos poderiam estar preenchidos com líquido, causariam a maior marcação com corante observada com - AH Plus.

No caso das paredes tratadas com o laser $\mathrm{Nd}: Y A G$, pela própria evaporação da umidade, eliminação da "smear layer", fusão de parte da dentina e diminuição da permeabilidade dentinária, o contato do cimento seria pleno com as paredes, não havendo sequer a interface da "smear layer".

Quanto ao Endofill, não há referências de que a umidade dentinária poderia provocar alguma deficiência no selamento; entretanto, as outras condições estão presentes e devem ser levadas em consideração. 
Alguns trabalhos ${ }^{14,64}$ têm demonstrado uma maior efetividade de remoção da "smear layer" pelo uso de diferentes tipos de laser, quando comparado com a solução de EDTA.

Assim, como a capacidade seladora dos cimentos a base de resina epóxica já foi exaustivamente pesquisada, mostrando-se superior aos outros cimentos, este trabalho, abre novas perspectivas de pesquisa em relação ao tratamento da parede dos canais radiculares, previamente à obturação, com o uso do laser Nd:YAG. 


\section{CONCLUSÕES}

Considerando as condições específicas da realização da pesquisa, com base nos resultados obtidos e a partir do que foi abordado na discussão, pode-se concluir que:

1) $O$ grupo I (Laser + AH Plus), foi o que apresentou menor média de infiltração apical, seguido dos grupos II (Laser + Endofill), III (EDTA + AH Plus) e IV (EDTA + Endofill).

2) $O$ cimento AH Plus apresentou melhor capacidade de selamento apical quando comparado com o cimento Endofill, independente do tratamento realizado previamente à obturação.

3) $O$ uso do laser $N d: Y A G$ proporcionou menores valores de infiltração apical que a solução de EDTA, independente do cimento utilizado.

4) Não houve diferenças estatísticas significantes na interação entre os tratamentos das paredes dentinárias previamente à obturação e os cimentos endodônticos utilizados.

5) A solução de EDTA trissódico removeu a "smear layer" do terço médio das paredes do canal radicular de uma forma mais eficaz quando comparada ao terço apical. Já o laser Nd:YAG teve uma maior ação no terço apical das paredes do canal radicular, onde observou-se um derretimento da "smear layer", e obliteração dos túbulos dentinários. 
REFERÊNCIAS BIBLIOGRÁFICAS 


\section{REFERÊNCIAS BIBLIOGRÁFICAS*}

1. ALEXANDER, J.B.; GORDON, T.M. A comparison of the apical seal produced by two calcium hydroxide sealers and a Grossman-type sealer when used with laterally condensed gutta-percha. Quint. Int., v.16, n.9, p.615-21, Sept. 1985.

2. ALMEIDA, W.A. et al. Evaluation of apical sealing of three endodontic sealers. Int. Endod. J., v.33, n.1, p.25-7, Jan. 2000.

3. ANIC, I.; TACHIBANA, H.; MASUMOTO, K. Permeability, morphologic and temperature changes of canal dentine walls induced by $\mathrm{Nd}: Y A G$, $\mathrm{CO}_{2}$ and argon lasers. Int. Endod. J., v.29, n.1, p.13-22, Jan. 1996.

4. ANIC, I. et al. Scanning electron microscopic study of dentin lased with argon, $\mathrm{CO}_{2}$ e Nd:YAG laser. J. Endod., v.24, n.2, p.77-81, Feb. 1998

5. BAKER, N.A. et al. Scanning electron microscope study of the efficacy of various irrigant solutions. J. Endod, v.1, p.127-35, Apr. 1975.

6. BARBIZAM, J.V.B. Estudo " in vitro" da infiltração marginal apical em canais radiculares obturados. Ribeirão Preto, 2001. 77 p. Dissertação (Mestrado) - Faculdade de Odontologia de Ribeirão Preto, Universidade de São Paulo.

7. BAUMGARTNER, J.C.; MADER, C.L. A scanning electron microscopic evaluation of four root canal irrigation regimens. J. Endod., v.13, n.4, p.147-57, Apr. 1987.

8. BEZERRA, A.G.; ARAKI, A.T.; CALDEIRA, C.L. Selamento marginal apical de canais irradiados com $\mathrm{Er}$ e $\mathrm{Nd}$ e obturados com AH Plus. Pesq. Odont. bras., v.15, p.99, 2001. Suplemento. Abst. A232. /Trabalho apresentado na $18^{\circ}$ Reunião Anual do SBPqO, Aguas de Lindoia, 2001/.

9. BRANDÃO, C.G.; MORAES, I.G.; BRAMANTE, C.M. Capacidade seladora apical de cimentos endodônticos ionoméricos. Rev. FOB, v.9, n.1/2, p.29-34, jan./jun. 2001.

\footnotetext{
* Normas recomendadas para o uso no âmbito da Universidade de São Paulo com base no documento "Referências Bibliográficas: exemplos", emanado do Conselho Supervisor do Sistema Integrado de Bibliotecas da USP em reunião de 20 de setembro de 1990.
} 
10. BRAYTON, S.M.; DAVIS, S.R.; GOLDMAN, M. Gutta-percha root canal fillings. An in vitro analysis. I. Oral Surg., v.35, n.2, p.226-31, Feb. 1973.

11. CALLAHAN, J.R. Sulfuric acid for openning root-canals. Dent. Cosmos, v.36, n.12, p.957-9, Dec. 1894 apud ZUOLO et al. Ação do EDTA e suas associações com tensoativos na permeabilidade da dentina radicular. Rev. Odont. USP, v.1, n.4, p. 18-23, out./dez. 1987.

12. CIUCCHI, B.; KHETTABI, M.; HOLZ, J. The effectiveness of different endodontic irrigation procedures on the removal of the smear layer: a scanning electron microscopy study. Int. Endod. J., v.22, n.1, p.21-8, Jan. 1989.

13. COSTA, I.R.S.; SCELZA, P.SCELZA, M.Z. Avaliação comparativa pelo MEV do EDTA $17 \%$ e ácido cítrico a $10 \%$ em três diferentes tempos. Pesq. Odont. bras., v.15, p.139, 2001. Suplemento. Abst. B073. /Trabalho apresentado na $18^{\circ}$ Reunião Anual do SBPqO, Aguas de Lindoia, 2001/.

14. CUSSIOLI, A.L. Estudo in vitro do efeito da aplicação do laser Er:YAG e da solução de EDTAC na superfície dentinária sobre a adesividade de diferentes cimentos endodônticos à base de resina epóxica. Ribeirão Preto, 1999. 72 p. Dissertação (Mestrado) Faculdade de Odontologia de Ribeirão Preto, Universidade de São Paulo.

15. DEDERICH, D.N.; ZAKARIASEN, K.L.; TULIP, J. Scannig electron microscopic analysis of canal wall dentin following neodymium-yttriumaluminum-garnet laser irradiation. J. Endod., v.10, n.9, p.428-31, Sept. 1984.

16. DRAKE, D.R. et al. Bacterial retention in canal walls in vitro: Effect of smear layer. J. Endod., v.20, n.2, p.78-82, Feb. 1994.

17. DUARTE, M.A.H. Avaliação de algumas propiedades físico químicas do cimento AH Plus puro e acrescido de hidróxido de cálcio. Bauru, 1999. 157p. Dissertação (Mestrado) - Faculdade de Odontologia de Bauru, Universidade de São Paulo. 
18. ECONOMIDES, $\mathrm{N}$. et al. Long-term evaluation of the influence of smear layer removal on the sealing ability of different sealers. J. Endod., v.25, n.2, p.123-25, Feb. 1999.

19. EINSTEIN, A. Zur Quantentheorie der Strahlung. Physiol. Z., v.18, p.121-8, 1917 apud PINHEIRO, A.L.B.; FRAME, J.W. Laser em Odontologia. Rev. gaúcha Odont., v.40, n.5, p.327-332, set./out. 1992.

20. ESTRELA, $C$. et al. Apical leakage using various sealers and root canal filling techniques. Braz. dent. J., v.5, n.1, p.59-63, 1994.

21. FEHR, F.R.; OSTBY, B.N. Effect of EDTAC and sulfuric acid on root canal dentine. Oral Surg., v.16, n.2, p.199-205, Feb. 1963.

22. FIDEL, R.A.S. et al. Adhesion of calcium hydroxide-containing root canal sealers. Braz. dent. J., v.5, n.1, p.53-57, 1994.

23. FRASER, J.G. Chelating agents: Their softening effect on root canal dentin. Oral Surg., v.37, n.5, p.803-11, May 1974.

24. GETTLEMAN, B.H.; MESSER, H.H.; ELDEEB, M.E.. Adhesion of sealer cements to dentin with and without the smear layer. J. Endod., v.17, n.1, p.15-20, Jan. 1991.

25. GOLDBERG, F.; ABRAMOVICH, A. Analysis of the effect of EDTAC on the dentinal walls of the root canal. J. Endod., v.3, n.3, p.101-5, Mar. 1977.

26. GORDON, J.P.; ZEIGLER, H.J.; TOWNES, C.H. The maser. A new type of amplifier, frequency standard and spectrometer. Phisiol. Rev., v.99, p.1264-74, 1955 apud PINHEIRO, A.L.B.; FRAME, J.W. Laser em Odontologia. Rev. gaúcha Odont., v.40, n.5, p.327-332, set./out. 1992.

27. GOYA, C. et al. Effects of pulsed Nd:YAG laser irradiation on smear layer at the apical stop and apical leakage after obturation. Int. Endod. J., v.33, n.3, p.266-71, May 2000.

28. GROSSMAN, L.I. An improved root canal cement. J.Amer. dent. Ass., v.56, n.3, p.381-5, Mar. 1958. 
29. GROSSMAN, L.I. Physical properties of root canal cements. J. Endod., v.2, n.6, p.166-74, June 1976.

30. GROSSMAN, L.I. Solubility of root canal cements. J. dent. Res., v.57, n.9/10, p.927, Sept./Oct. 1978.

31. GUTIERREZ, J.H. et al. The risk of intentional dissolution of the smear layer after mechanical preparation of root canals. Oral Surg., v.70, n.1, p.96-108, July 1990.

32. HAIKEL, $Y$. et al. A new method for the quantitative analysis of endodontic microleakage. J. Endod., v.25, n.3, p.172-7, Mar. 1999.

33. HARASHIMA, T. et al. Effect of Nd:YAG laser irradiation for removal of intracanal debris and smear layer in extracted human teeth. J. Clin. Laser Med. Surg., v.15, n.3, p.131-5, 1997.

34. JACOBSON, H.L. et al. Microbial leakage evaluation of the continuous wave of condensation. J. Endod., v.28, n.4, p.269-71, Apr. 2002.

35. JOHNSON, L.F. Optical meser characteristics of rare-earth ion in crystals. J. Appl. Physiol., v.34, p.897-909, 1961 apud PINHEIRO, A.L.B.; FRAME, J.W. Laser em Odontologia. Rev. gaúcha Odont., v.40, n.5, p.327-332, set./out. 1992.

36. KENNEDY, W.A.; WALKER III, W.A.; GOUGH, R.W. Smear layer removal effects on apical leakage. J. Endod., v.12, n.1, p.21-7, Jan. 1986.

37. KERSTEN, H.W.; MOORER, W.R. Particles and molecules in endodontic leakage. Int. Endod. J., v.22, n.3, p.191-9, May 1989.

38. KOCH, K.; MIN, P.S.; STEWART, G.G. Comparison of apical leakage between Ketac Endo sealer and Grossman sealer. Oral Surg., v.78, n.6, p.784-7, Dec. 1994.

39. KUGA, M.C. et al. A. Infiltração marginal em obturações de canais radiculares decorrentes de materiais obturadores. Rev. paul. Odont., v.12, n.6, p.2-6, nov./dez. 1990. 
40. LAN, W.H. Temperature elevation on the root surface during Nd:YAG laser irradiation in the root canal. J. Endod., v.25, n.3, p.155-6, Mar. 1999.

41. MAIMAN, T.H. Stimulated emission of radiation in ruby. Nature, v.187, p.493-4, 1960 apud PINHEIRO, A.L.B.; FRAME, J.W. Laser em Odontologia. Rev. gaúcha Odont., v.40, n.5, p.327-332, set./out. 1992.

42. MATLOFF, I.R. et al. A Comparison of methods used in root canal sealability studies. Oral Surg., v.53, n.2, p.203-8, Feb. 1982.

43. MATSUOKA, E.; KIMURA, Y.; MATSUMOTO, K. Studies on the removal of debris near the apical seats by Er:YAG laser and assessment with fiberscope. J. Clin. Laser Med. Surg., v.16, n.5, p.255-61, Oct. 1998.

44. MAZOTTI, D.; BONETTI FILHO, I. Avaliação comparativa in vitro da capacidade de preenchimento do sistema de canais radiculares de diferentes técnicas de obturação. Pesq. Odont. bras., v.15, p.137, 2001. Suplemento. Abst. B060. /Trabalho apresentado na $18^{\circ}$ Reunião Anual do SBPqO, Aguas de Lindoia, 2001/.

45. MELLO, J.B.; MELLO, G.P.S. Laser em Odontologia. Santos, Ed. Santos, 2001.

46. MELLO, I.; ANTONIAZZI, J.H.; ROBAZZA, C.R.C. Influência do laser Er:YAG na infiltração marginal apical de quatro cimentos obturadores. Pesq. Odont. bras., v.15, p.137, 2001. Suplemento. Abst. B054. /Trabalho apresentado na $18^{\circ}$ Reunião Anual do SBPqO, Aguas de Lindoia, 2001/.

47. MICHELICH, V.J.; SCHUSTER, J.S.; PASHLEY, D.H. Bacterial penetration of human dentin in vitro. J. dent. Res., v.59, n.8, p.1398403, Aug. 1980.

48. MILETIC, I. et al. Leakage of five root canal sealers. Int. Endod. J., v.32, n.5, p.415-8, Sept. 1999.

49. MISERENDINO, L.J.; LEVY, G.C.; RIZOIU, I.M. Effects of Nd:YAG Laser on the permeability of Root Canal Wall Dentin. J. Endod., v.21, n.2, p.83-7, Feb. 1995. 
50. MOSS, H.D.; ALLEMANG, J.D.; JOHNSON, J.D.. Philosophies and practices regarding the management of the endodontic smear layer: results from two surveys. J. Endod., v.27, n.8, p.537-9, Aug. 2001.

51. NIKIFORUK, G:; SCREEBNY, L. Desmineralization of hard tissues by organic chelating agents at neutral pH. J. dent. Res., v.32, n.6, p.859-67, Dec. 1953

52. OKSAN, T.; AKTENER, B.O.; SEN, B.H.; TEZEL, H.. The penetration of root canal sealers into dentinal tubules. A scanning electron microscope study. Int. Endod. J., v.26, n.5, p.301-5, Sept. 1993.

53. OLIVEIRA, D.P. et al. Estudo comparativo da limpeza das paredes dos canais radiculares. Pesq. Odont. bras., v.15, p.79, 2001. Suplemento. Abst. A070. /Trabalho apresentado na $18^{\circ}$ Reunião Anual do $\mathrm{SBPqO}$, Aguas de Lindoia, 2001/.

54. OSTBY, B.N. Chelation in root canal therapy. Ethylenediamine tetraacetic acid for cleasing and windening of root canals. Odont. T., v.65, n.2, p.3-11, Feb. 1957 apud ZUOLO et al. Ação do EDTA e suas associações com tensoativos na permeabilidade da dentina radicular. Rev. Odont. USP, v.1, n.4, p. 18-23, out./dez. 1987.

55. PARK, D.S. et al. Effect of Nd:YAG laser irradiation on the apical leakage of obturated root canals: an electrochemical study. Int. Endod. J., v.34, n.4, p.318-21, June 2001.

56. PASSARINHO NETO, J.G. et al. Avaliação da infiltração apical utilizando diferentes soluções quelantes. Pesq. Odont. bras., v.15, p.62, 2001. Suplemento. Abst. I324. /Trabalho apresentado na $18^{\circ}$ Reunião Anual do SBPqO, Aguas de Lindoia, 2001/.

57. PICCOLOMINI, R. et al. Bacteriological evaluation of the effecf of $\mathrm{Nd}: Y A G$ laser irradiation in experimental infected root canals. $J$. Endod., v.28, n.4, p.276-8, Apr. 2002.

58. POMMEL, L.; CAMPS, J. In vitro apical leakage of system $B$ compared with other filling techniques. J. Endod., v.27, n.7, p.449-51, July 2001. 
59. RAM, Z. Chelation in root canal therapy. Oral Surg., v.49, n.1, p.64-74, Jan. 1980.

60. RIBEIRO,G.G.; MEDINA, J.; MORAES, I.G.. Soluções irrigadoras versus selamento apical de obturações de canais radiculares. Pesq. Odont. bras., v.15, p.138, 2001. Suplemento. Abst. B061. /Trabalho apresentado na $18^{\circ}$ Reunião Anual do SBPqO, Aguas de Lindoia, 2001/.

61. SCHAWLON, A.L.; TOWNES, C.H. Infrared and optical masers. Phys. Rev., v.102, p.1940-9, 1958 apud PINHEIRO, A.L.B.; FRAME, J.W. Laser em Odontologia. Rev. gaúcha Odont., v.40, n.5, p.327-332, set./out. 1992.

62. SPERBECK, B.; SCOTT, W.T. An evaluation of apical leakage using glass ionomer and Grossman's sealers. Dentistry, v.13, n.3, p.17-21, Oct. 1993.

63. STABHOLZ, A. et al. Effects of Nd:YAG laser on apical seal of teeth after apicoectomy and retrofill. J. Endod., v.18, n.8, p.371-5, Aug. 1992.

64. TAKEDA, F.H. et al. Comparative study about removal of smear layer by three types of lasers devices. J. Clin. Laser Med. Surg., v.16, n.2, p.117-122, Mar. 1998a.

65. TAKEDA, F.H. et al. Efficacy of Er:YAG laser irradiation in removing debris and smear layer on root canal walls. J. Endod., v.24, n.8, p.54851, Aug. 1998b.

66. TAKEDA, F.H. et al. A comparative study of the removal of smear layer by three endodontic irrigants and two types of laser. Int. Endod. J., v.32, n.1, p.32-39, Jan. 1999.

67. TIMPAWAT, S.; AMORNCHAT, C.; TRISUWAN, W. Bacterial coronal leakage after obturation with three root canal sealers. J. Endod., v.27, n.1, p.36-9, Jan. 2001.

68. TIMPAWAT, S.; VONGSAVAN, N.; MESSER, H.H. Effect of removal of the smear layer on apical microleakage. J. Endod., v.27, n.5, p. 351-3, May 2001. 
69. TURKMEN, $C$. et al. Effect of $\mathrm{CO}_{2}, \mathrm{Nd}$ :yag, and ArF Excimer lasers on dentin morphology and pulp chamber temperature: An in vitro study. J. Endod., v.26, n.11, p.644-8, Nov. 2000.

70. WEICHMAN, J.A.; JOHNSON, F.M. Laser use in endodontics. A preliminary investigation. Oral Surg., v.31, n.3, p.416-20, Mar. 1971.

71. WEICHMAN, J.A.; JOHNSON, F.M.; NITTA, L.K. Laser use in endodontics. Part II. Oral Surg., v.34, n.5, p.828-30, Nov. 1972.

72. WIGDOR, H. et al. The effect of lasers on dental hard tissues. J.Amer. dent. Ass., v.124, n.1, p.65-70, Feb. 1993.

73. YAMADA, R.S. et al. A scanning microscopic comparison of a high volume final flush with several irrigating solutions. J. Endod., v.9, n.4, p.13742, Apr. 1983.

74. ZAKARIASEN, K.L.; DEDERICH, D.N.; TULIP, J. $C_{2}$ and Nd:YAG Laser Fusion of Dentin Plugs in Root Canals. J. Endod., v.10, n.3, p.145, Mar. 1985./ Abstract n.30/.

75. ZAKARIASEN, K.L.; DEDERICH, D.N.; TULIP, J. S.E.M. analysis of dyed canal dentin following Nd:YAG laser irradiation. J. dent. Res., v.64, p.239, 1985. Special issue. /Abstract n.579/.

76. ZHANG, C. et al. Effects of pulsed Nd:YAG laser irradiation on root canal wall dentin with different lasers initiators. J. Endod., v.24, n.5, p.352-5, May 1998.

77. ZMENER, O. et al. Sealing ability properties of a new epoxy resin-based root-canal sealer. Int. Endod. J., v.30, n.5, p.332-4, Sept. 1997.

78. ZUOLO, M. et al. Ação do EDTA e suas associações com tensoativos na permeabilidade da dentina radicular. Rev. Odont. USP, v.1, n.4, p.1823, out./dez. 1987. 
ABSTRACT 


\begin{abstract}
This study aimed at evaluating the influence of applying $\mathrm{Nd}$ :YAG laser or an EDTA solution in the root canal walls, on the sealing capacity of fillings performed with two sorts of cements. Sixty-eight human lower premolars, being 62 used for the analysis of apical sealing and 6 to analyse the wall characteristics of root canals under SEM, following treatment with trisodic EDTA and Nd:YAG laser were utilized. The teeth had their crowns cut at the cementoenamel junction and the root canals were instrumented through automatized technique with standardization of apical foramen by a \# $25 \mathrm{Kerr}$ file. Upon completion of root canal instrumentation, the external root surfaces were impermeabilized, except for the foramen. The roots were then divided into 4 groups of 15, according to the type of treatment performed on the root canal walls and the type of cement utilized in the filling. Group I - application of Nd:YAG laser and filling with AH Plus cement; Group II - application of Nd:YAG laser and filling with Endofill cement; Group III - application of EDTA for 5 minutes and filling with AH Plus cement; Group IV - application of EDTA for 5 minutes and filling with Endofill cement. Two teeth served as negative and positive controls. Afterwards, the roots were immersed in a $2 \%$-methylene blue dye, for 48 hours. Wearing of the roots took place following the removal of impermeabilization for the reading of leakage magnitude, by means of a light microscope through planimetry technique. The results indicated AH Plus cement as the one to allow the least apical leakage, as well as Nd:YAG laser application, when utilized in the treatment of root canal walls, prior to filling.
\end{abstract}

